\title{
Elucidating Field Retting Mechanisms of Hemp Fibres for Biocomposites: Effects of Microbial Actions and Interactions on the Cellular Micro-morphology and Ultrastructure of Hemp Stems and Bast Fibres
}

\author{
Dinesh Fernando, ${ }^{\mathrm{a}, *}$ Anders Thygesen, ${ }^{\mathrm{b}}$ Anne S. Meyer, ${ }^{\mathrm{b}}$ and Geoffrey Daniel ${ }^{\mathrm{a}}$
}

Field retting is an industrial process for extracting valuable bast fibres from hemp. In this study, molecular, chemical, and scanning electron microscopy studies were employed to understand the field retting mechanisms involving microbiota, including microbial community dynamics, hemp colonization, functions/interactions, and hemp biodegradation. This study for the first time revealed the coexistence of bacterial-fungal interactions during retting and showed progressive microbial breakdown of the stems. Using scanning electron microscopy, evidence for microbial activities/interactions within the stems was obtained, which helped to understand hemp retting mechanisms. The collective findings showed that: a) initially, easily accessible food within the hemp stems attracted and supported microbial invasion and decay, with activities influenced by the stem anatomy, chemistry, and morphology; b) filamentous fungi as key players in the early stages remarkably contributed to efficient fibre defibration; $c$ ) extended retting enhanced the bacterial activities, including bacterial-fungal interactions and their dominant role within the community; d) bacterial attraction and activities were promoted by bacterial mycophagy with a set of different phenotypic behaviours for nutrients and fungal highways for transport within the stems; and e) bast fibre degradation leading to inferior quality during prolonged retting was caused by ultrastructural modifications to all of the major fibre cell wall layers.

Keywords: Bacterial-fungal interactions (BFIs); Bacterial mycophagy; Fibre cell wall ultrastructure; Field retting; Hemp fibres; Microbial dynamics; Scanning electron microscopy (SEM)

Contact information: a: Department of Forest Biomaterials and Technology, Swedish University of Agricultural Science (SLU), P. O. Box 7008, SE-750 07 Uppsala, Sweden; b: Protein Chemistry \& Enzyme Technology, DTU Bioengineering, Building 221, Technical University of Denmark, 2800 Kongens Lyngby, Denmark; *Corresponding author: dinesh.fernando@slu.se

\section{INTRODUCTION}

Hemp (Cannabis sativa L.) is a multi-purpose annual plant that produces natural fibres (i.e., bast fibres) and has gained increasing interest because of the industrial potential of the plant in the construction, pulp and paper, and textiles industries, and as a reinforcement material to replace synthetic fibre-reinforced plastics (Corbière-Nicollier et al. 2001; Pickering et al. 2007; Amaducci and Gusovius 2010; Andre et al. 2016; Liu et al. 2017b). Hemp is also a renewable fibre resource that provides integrated ecological (i.e., renewability, low emission of toxic fumes, biodegradability, and biocompatibility) and economic benefits (Corbière-Nicollier et al. 2001; Joshi et al. 2004; Tahir et al. 2011). Hemp provides composite manufacturers with several advantages, including a low cost, 
high mechanical properties (stiffness and strength) combined with a low density, flexibility, and reduced tool wear during processing (Fan et al. 2011; Tahir et al. 2011; Liu et al. 2016; Pickering et al. 2016).

Hemp bast fibres (also generally referred as "fibres") are cellulose-rich sclerenchymatous cells comprised of both primary and secondary fibres that are located in the cortex below the outer epidermis, which forms a multi-layered ring that encircles the core xylem. In hemp stems, bast fibres are characterized by thick secondary cell walls, whose chemical and morphological structures are distinct from those of the core xylem fibres. Hemp fibre cell walls are natural composites similar to wood fibres and their main components are highly crystalline cellulose, hemicellulose, lignin, and pectin (Crônier et al. 2005; Wang et al. 2007; Liu et al. 2015). Bast fibres are intimately associated forming fibre bundles (i.e., several fibre cells grouped together as clusters) via pectin and ligninrich middle lamellae (ML). Individual bundles are held together by delicate living parenchyma cells, whose cell walls are composed primarily of pectic substances (Liu et al. 2015).

One major step for the industrial use of bast fibres (e.g., for biocomposites) is improved and efficient fibre processing (i.e., fibre extraction), where the main principle is to remove the cementing materials between the fibres and fibre bundles to obtain individual cellulose-rich fibres with minimum damage. The isolation of cellulosic fibres from nonfibrous tissues and woody parts of hemp stems (i.e., retting) poses a major challenge that has considerable bearing on the subsequent chemical and physical properties of single fibres. In particular, damage leads to a greater variability in the mechanical performance of fibres as reinforcing agents, which renders them unsuitable for use in high-grade composite materials (Easson and Molly 1996; Liu et al. 2015; Pickering et al. 2016). For example, manually extracted flax fibres have been shown to have a $20 \%$ higher strength than those extracted mechanically (Bos et al. 2002). Traditionally, bast fibres are extracted using either field (dew) or water retting (Di Candilo et al. 2010; Jankauskienè et al. 2015). The impact on the quality of the extracted fibres largely depends on environmental factors, like the agro-climatic conditions (i.e., rainfall and temperature), underlying soil, and most importantly the retting duration (Tahir et al. 2011; Das et al. 2014; Liu et al. 2015; Ribeiro et al. 2015).

Field retting is basically a biochemical process, where partial decomposition of plant stems occurs under native conditions. This facilitates the separation of bast fibres from hemp stems during subsequent mechanical processing (decortication) and represents a key process for obtaining high-quality raw materials (Easson and Molly 1996; Tahir et al. 2011; Das et al. 2014). The main purpose is to degrade the binding materials (i.e., pectin) between the individual fibres and fibre bundles, and other cementing compounds (hemicellulose and lignin) in the ML using a pool of microbiota (Akin 2013; Ribeiro et al. 2015). Previously, fungi were considered the major active microflora responsible for dew retting (Fuller and Norman 1944). However, recent studies have shown a complex microbial community with both bacteria (e.g., Pseudomonas and Escherichia coli) and fungi (Cryptococcus and Cladosporium) causing enzymatic hydrolysis of pectin via pectinases (i.e., polygalacturonase, pectin lyases, and pectin esterases) (Alkorta et al. 1998; Munshi and Chatto 2008; Ribeiro et al. 2015). However, natural retting is difficult to control and has inherent drawbacks, such as inferior fibre properties from over retting, heterogeneity in the mechanical properties of the extracted fibres, and negative environmental impacts from water pollution (Hu et al. 2012). Because of these concerns and costs related to labour and drying during anaerobic water retting, aerobic field retting 
is preferred, where hemp stems are left on fields after cutting and exposed to the action of microbes for approximately 2 weeks to 10 weeks (Henriksson et al. 1997). However, despite a growing number of studies on the physical and chemical property changes that occur during retting, there is a lack of knowledge on the nature and activities of microbes and the resulting micro-morphological and ultrastructural changes that occur in hemp stems and bast fibres during this process.

Hemp bast fibres are produced through the physical and chemical breakdown of the stem cellular structure achieved by the collective action of fungi and bacteria. However, the two microflorae, while similar to that formed in other naturally decomposing habitats (e.g., litter environments), have major differences in their microbial biomass nutrient demands, which should influence decomposition, including the use of cellular plant materials as a carbon source (Sinsabaugh et al. 2009; Keiblinger et al. 2010). Recent research has revealed the coexistence of bacteria and fungi in many natural environments that leads to bacterial-fungal interactions (BFIs). These interactions can render both benefits and/or antagonisms within the habitat and are shown to form physical and metabolically interdependent consortia that collectively affect the habitat, as shown by litter decomposition (Tarkka et al. 2009; Frey-Klett et al. 2011). Field retting is contemporary with other natural environments, but no attempt has been made to identify BFIs that exist during hemp retting and thereby whether they are responsible for regulating partial decomposition of hemp stems.

The objectives of the present work were to obtain a more comprehensive understanding of field retting mechanisms concerning micro-morphological and ultrastructural aspects, and identify BFIs that could impact the retting and quality of bast fibres. Molecular identification of the microbial community and an in-depth study using scanning electron microscopy (SEM) were performed on freshly harvested and field-retted hemp stems over a period of 10 weeks to gain information on the microbial colonization and development, and progressive morphological and ultrastructural changes that occurred in the hemp stems and bast fibres. To the best of our knowledge, our study represents the first comprehensive study on hemp field retting that revealed coexisting interactions of BFIs related to progressive microbial break down of plant materials permitting extraction of bast fibres. This study will be able to provide important clues for hemp/plant fibre industries that utilize retting processes for obtaining reinforcing fibres that have a constant quality and high yield, and may also assist in averting negative impacts on the environment. Such knowledge can provide an important foundation for future studies on field retting, suggesting better implementation of management practices: speeding up the process while reaching optimum degree of retting and efficient removal of bast fibres with betterpreserved fibre properties.

\section{EXPERIMENTAL}

\section{Plant Materials}

Hemp (Cannabis sativa L.) variety USO-31 was grown in France (planted on 5 May 2013) and harvested in the early (flowering stage; 18 July 2013) and late (seed maturity; 6 September 2013) growth stages based on the definition of Mediavilla et al. (1998) for code 2101 and 2204, respectively. The details of the growing conditions, harvesting, etc. can be found in Liu et al. (2015). Hemp stem samples for the study were randomly selected from the two harvests. 
The early harvest stems were subjected to 50-d and 70-d retting periods and the late harvest stems were subjected to 7-d, 14-d, and 20-d retting periods. For more details, consult Liu et al. (2015). After field retting, the samples were kept frozen until the laboratory and microscopy studies were conducted. Table 1 summarizes all sample types used and their respective analyses.

Table 1: Summary of Different Hemp Stems Sample Types Used in the Study and Relevant Properties/analysis Performed Including Treatments Before the Respective Analyses

\begin{tabular}{|c|c|c|c|c|c|c|c|c|}
\hline \multirow{2}{*}{ Properties and Analyses Performed } & \multicolumn{3}{|c|}{ Early Harvest } & \multicolumn{3}{|c|}{ Late Harvest } & \multicolumn{2}{c|}{$\begin{array}{c}\text { Post-treatments } \\
\text { Before Respective } \\
\text { Analysis }\end{array}$} \\
\cline { 2 - 12 } & $0 \mathrm{~d}^{\mathrm{a}}$ & $50 \mathrm{~d}^{\mathrm{a}}$ & $70 \mathrm{~d}^{\mathrm{a}}$ & $0 \mathrm{~d}^{\mathrm{a}}$ & $7 \mathrm{~d}^{\mathrm{a}}$ & $14 \mathrm{~d}^{\mathrm{a}}$ & $20 \mathrm{~d}^{\mathrm{a}}$ & \\
\hline Chemical: elemental composition & $\mathrm{X}$ & $\mathrm{X}$ & $\mathrm{X}$ & $\mathrm{X}$ & $\mathrm{X}$ & $\mathrm{X}$ & $\mathrm{X}$ & $\begin{array}{c}\text { Washing, peeling and } \\
\text { air drying }\end{array}$ \\
\hline $\begin{array}{c}\text { Chemical: dry matter calculation } \\
\text { Molecular identification of microbes: } \\
\text { PCR, gene sequencing }\end{array}$ & $\mathrm{X}$ & $\mathrm{X}$ & $\mathrm{X}$ & $\mathrm{X}$ & $\mathrm{X}$ & $\mathrm{X}$ & $\mathrm{X}$ & $\begin{array}{c}\text { Washing, peeling and } \\
\text { air drying }\end{array}$ \\
\hline $\begin{array}{c}\text { Micro-morphology and ultrastructure: } \\
\text { SEM on transverse (T) stem sections }\end{array}$ & $\mathrm{X}$ & $\mathrm{X}$ & $\mathrm{X}$ & $\mathrm{X}$ & $\mathrm{X}$ & $\mathrm{X}$ & $\mathrm{X}$ & $\begin{array}{c}\text { Stored frozen until } \\
\text { analysis }\end{array}$ \\
\hline $\begin{array}{c}\text { Micro-morphology and ultrastructure: } \\
\text { SEM on longitudinal (L) stem sections }\end{array}$ & $\mathrm{X}$ & $\mathrm{X}$ & $\mathrm{X}$ & $\mathrm{X}$ & $\mathrm{X}$ & $\mathrm{X}$ & $\mathrm{X}$ & $\begin{array}{c}\text { Stored frozen until } \\
\text { analysis }\end{array}$ \\
\hline
\end{tabular}

a Retting period in days (sampling point)

To remove fungal materials from the stem surfaces (after retting) and remove bast fibres from the rest of the woody core, both control and retted hemp stem samples were washed in water and manually peeled, except for the stem samples used for the microscopy studies. The resulting bast fibres were then dried at $50{ }^{\circ} \mathrm{C}$ for $24 \mathrm{~h}$ before the chemical analyses described below.

\section{Dry Matter and Compound Recovery}

The dry matter (mass loss) and elemental composition of the fibres were calculated to assess the degradation of the hemp bast fibres from field retting for different time periods. The chemical composition of the dried bast fibres $\left(50{ }^{\circ} \mathrm{C}\right.$ for $\left.12 \mathrm{~h}\right)$ was analysed after grinding them with a microfine grinder (IKA MF 10.1, IKA ${ }^{\circledR}$-Werke $\mathrm{GmbH}$, Staufenim Breisgau, Germany) and Soxhlet extracting (Gerhardt EV6 ALL/16 No. 100012, C. Gerhardt GmbH \& Co. KG, C., Königswinter, Germany) the fibre particles approximately $1 \mathrm{~mm}$ in size using a toluene-ethanol-acetone $(4: 1: 1 \mathrm{v} / \mathrm{v})$ solution to remove the extractives. Following acid hydrolysis of the extractive-free fibres, chemical analyses of monosaccharides were done using high-performance anion-exchange chromatography with pulsed amperometric detection (HPAEC-PAD) (Dionex ICS-3000, ThermoFisher Scientific, Roskilde, Denmark). The Klason lignin was measured gravimetrically, as described by Liu et al. (2017a). The recovery values for the monosaccharides were estimated from the parallel runs, as described by Arnous and Meyer (2008). The 
composition of the major hemp fibre polymers was determined, including the cellulose (glucose), pectin (galacturonic acid (GalA), galactose, arabinose, and rhamnose), hemicellulose (xylose and mannose), and Klason lignin contents.

The initial recoveries of the dry matter after field retting (early harvest: $50 \mathrm{~d}$ of retting; late harvest: $7 \mathrm{~d}$ and $14 \mathrm{~d}$ of retting) were estimated by assuming zero degradation of the lignin and cellulose, which can be justified because initially mainly the pectin was degraded according to the compositional changes. After $70 \mathrm{~d}$ of retting for the early harvest and $21 \mathrm{~d}$ of retting for the late harvest, the dry matter loss was calculated based on the cellulose loss because the concentrations of the other polymers appeared constant or slightly increased. The concentrations used are shown in Figs. 1a and 1b. The following equation was used for calculating the dry matter (DM) recovery during the initial stages by assuming no cellulose and lignin degradation for a time $(x, \mathrm{~d})$ less than or equal to the retting time $\left(t_{1}, \mathrm{~d}\right)\left(t_{0}=0 \mathrm{~d}\right.$ and $t_{1}=50 \mathrm{~d}$ for the early harvest and $14 \mathrm{~d}$ for the late harvest):

$$
\text { Recovery } y_{\mathrm{DM}}\left(t_{\mathrm{x}}\right)=\frac{\text { Conc }_{\text {cellulose }+ \text { lignin }, \mathrm{t}_{0}}}{\text { Conc }_{\text {cellulose }+ \text { lignin }, \mathrm{t}_{\mathrm{x}}}}
$$

For the later periods of retting, where mainly cellulose degradation occurred for $x$ greater than $t_{1}$, the DM recovery was calculated with the following equation:

$$
\text { Recovery }_{\mathrm{DM}}\left(t_{\mathrm{x}}\right)=\text { Recover }_{\mathrm{DM}}\left(t_{1}\right) \cdot \frac{\text { Conc }_{\text {cellulose }, \mathrm{t}_{\mathrm{x}}}}{\text { Conc }_{\text {cellulose }, \mathrm{t}_{1}}}
$$

The composition of the major polymers (i.e., cellulose, lignin, and pectin) in the samples was calculated relative to the amount of DM when field retting was initiated as recovery $(\operatorname{Rec})$ :

$$
\begin{aligned}
& \operatorname{Rec}_{\text {Cellulose,conc }}\left(t_{\mathrm{x}}\right)=\operatorname{Recovery}_{\mathrm{DM}}\left(t_{\mathrm{x}}\right) \cdot \operatorname{Conc}_{\text {cellulose }, \mathrm{t}_{\mathrm{x}}} \\
& \operatorname{Rec}_{\text {Cellulose,conc }}\left(t_{\mathrm{x}}\right)=\operatorname{Recover}_{\mathrm{DM}}\left(t_{\mathrm{x}}\right) \cdot \operatorname{Conc}_{\text {cellulose, } \mathrm{t}_{\mathrm{x}}} \\
& \operatorname{Rec}_{\text {Pectin,conc }}\left(t_{\mathrm{x}}\right)=\operatorname{Recovery}_{\mathrm{DM}}\left(t_{\mathrm{x}}\right) \cdot \\
& \operatorname{Conc}_{(\mathrm{Gal}+\text { Galactose }+ \text { Arabinose }+ \text { Rhamnose }), \mathrm{t}_{\mathrm{x}}}
\end{aligned}
$$

\section{Fungal and Bacterial Identification by Gene Sequencing}

The hemp bast fibres were isolated manually from the hemp plant stems and characterized for the bacterial and fungal community, as described in detail by Liu et al. (2017a). In brief, fibre samples $\left(2 \mathrm{~mm}^{2}\right)$ were extracted to obtain genomic DNA using the PowerBiofilm ${ }^{\mathrm{TM}}$ DNA Isolation Kit (MO-BIO, Carlsbad, USA). Polymerase chain reaction amplification was done using the $16 \mathrm{~S}$ ribosomal ribonucleic acid primers $27 \mathrm{~F}$ (5'AGAGTTTGATCATGGCTCA-3') and 1492R (5'-CGG TTA CCT TGT TAC GACTT-3') for bacteria, and ITS5 (5'-GGA AGT AAA AGT CGT AAC AAGG-3') and ITS4 (5'-TCC TCC GCT TAT TGA TAT GC-3') for fungi. Cloning was performed using the pJet1.2/Blunt cloning vector $(50 \mathrm{ng} / \mu \mathrm{L})$ and T4 DNA ligase $(5 \mathrm{U} / \mu \mathrm{L})$, and the ligated product transformed into $E$. coli $\mathrm{DH} 5 \alpha$. Purified plasmids were sequenced using the 27F primer for bacteria and ITS4 primer for fungi. A GenBank nucleotide database search was conducted using the BLAST algorithm to identify the sequences. The identified sequences are published in the EMBL Nucleotide Sequence Database with accession numbers LT622055 and LT622085 outlined in Liu et al. (2017a) for bacteria and fungi, respectively.

The fraction of each fungal genus was determined relative to the total number of fungal sequences at each retting time point, while the fractions of bacterial sequences were 
similarly determined relative to the total number of bacterial sequences. The calculations for bacteria were done based on Liu et al. (2017a) and were as follows: Pseudomonas spp. = Pseudomonas argentinensis + Pseudomonas rhizosphaerae + Pseudomonas syringae; Pantoea spp. $=$ Pantoea agglomerans + Pantoea brenneri $;$ Massilia $\mathrm{spp} .=$ M. aurea , and Rhizobium spp. $=R$. soli. The calculations for the fungi were done based on Liu et al. (2017a) and were as follows: Alternaria spp. $=$ A. brassicae + A. infectoria $;$ Cladosporium spp. = Cladosporium antarcticum + Cladosporium macrocarpum + Cladosporium uredinicola; Stemphylium spp. $=$ S. globuliferum; and Cryptococcus spp. $=$ Cryptococcus carnescens + Cryptococcus festucosus spp. + Cryptococcus victoriae spp.

\section{Scanning Electron Microscopy}

Never-dried hemp stem samples that were field-retted and control samples (i.e., non-retted) for the SEM investigations were taken either directly after treatment or thawed to room temperature if they were stored frozen after harvesting (under $-20{ }^{\circ} \mathrm{C}$ ). Stem sections $(5 \mathrm{~cm} \times 2 \mathrm{~cm})$ were cut from the hemp stem samples using stereomicroscopy for the surface and cross-sectional observations for each treatment and control sample. The sections were fixed in a mixture of $3 \% \mathrm{v} / \mathrm{v}$ glutaraldehyde and $2 \% \mathrm{v} / \mathrm{v}$ paraformaldehyde in $0.1 \mathrm{M}$ sodium cacodylate buffer $(\mathrm{pH}=7.2)$ for $4 \mathrm{~h}$ at room temperature. After three washes in $0.1 \mathrm{M}$ buffer and two washes in water $(10 \mathrm{~min}$, each), the samples were dehydrated in a series of solutions with an increasing ethanol concentration (20\% to $100 \%$ with $20 \%$ steps for $10 \mathrm{~min}$, each), followed by acetone (3:1, 1:1, and 1:3 ethanol:acetone, and finally $100 \%$ acetone for $10 \mathrm{~min}$, each). The samples were subsequently critical point dried in an Agar E3000 critical point dryer (Quorum Technologies Ltd., East Essex, UK) using $\mathrm{CO}_{2}$ as the drying agent, mounted on stubs using double-sided tape, and coated with gold using an Emitech K550X sputter device (Emitech Ltd., Kent, UK). The observations were made using a Philips XL 30 ESEM (FEI, Eindhoven, Netherlands) operated at $10 \mathrm{kV}$ to $15 \mathrm{kV}$, and the images were recorded digitally.

\section{RESULTS AND DISCUSSION}

\section{Mass Loss and Lignocellulose Degradation}

The mass recovery reached similar values $(84 \%)$ during both the early (i.e., $70 \mathrm{~d}$ ) and late harvests (i.e., $21 \mathrm{~d}$ ) (Figs. 1c and 1d). The slow mass loss rate after the early harvest presumably resulted from the high daily temperatures with low precipitation during August, which resulted in faster evaporation (Liu et al. 2015). Hence, the dryer hemp stems had a lower microbial activity and required an extended field retting duration. Initially, pectin degradation occurred during both the early and late harvests (Figs. 1c and 1d) with a higher rate during the late harvest, followed by cellulose degradation that was more pronounced after $50 \mathrm{~d}$ of retting (Fig. 1c). Lignin with a predominance of guaiacyl (G) units (syringyl (S)/G ratio of 0.8) (del Río et al. 2007) was recalcitrant to microbial degradation and accumulated over the entire retting period (Figs. 1a, 1b, 1c, and 1d). However, the lignin content of the hemp fibres was low and thus the total lignin only marginally increased. The level and type of lignin in wood cell walls is generally considered to be a major factor that influences wood decay, with G-rich lignified fibres more resistant to decay than those containing S-rich lignin (Faix et al. 1985; Blanchette 1991). This knowledge combined with previous data on similar samples that showed a lack 
of ligninolytic Basidiomycota fungi, especially during the latter part of hemp field retting (Liu et al. 2017a), explained the observed lignin accumulation.

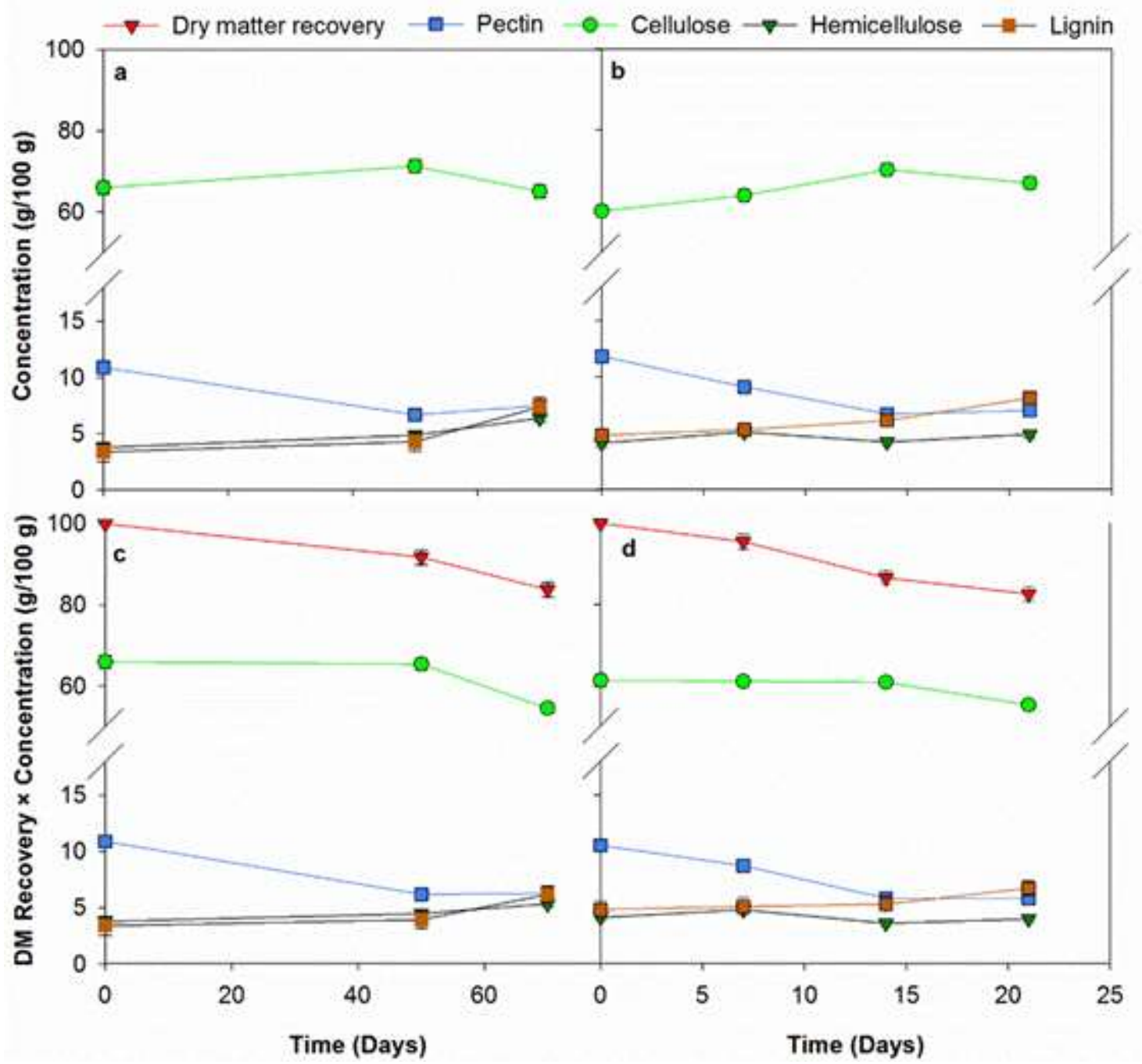

Fig. 1. Concentration ( $a$ and b) and recovery ( $c$ and d) of the DM, cellulose, pectin, hemicellulose, and lignin relative to the initial DM of the hemp fibres for the early ( $a$ and $c$ ) and late (b and d) harvest times

\section{Microbial Compositional Changes during Retting after Late Harvest}

Figure 2 shows the development in the dominant fungal and bacterial genera versus time for different retting periods (i.e., $0 \mathrm{~d}, 7 \mathrm{~d}, 14 \mathrm{~d}$, and $20 \mathrm{~d}$ ) based on the gene sequencing data (Liu et al. 2017a). The results showed a pronounced development of the microbial communities with the fungus Cryptococcus spp., which was the only genus belonging to the Basidiomycota present up to $7 \mathrm{~d}$ after harvest and represented the initial invaders (Fig. 2a). After further retting, it was succeeded by Ascomycota fungi. The low presence of Basidiomycota fungi concurred with the changes in the stem chemical composition, where lignin remained throughout the retting period. Cladosporium spp. and Stemphylium spp. (both Ascomycetes) dominated the initial and late periods of retting. Also, Alternaria became increasingly present over the entire retting period. 

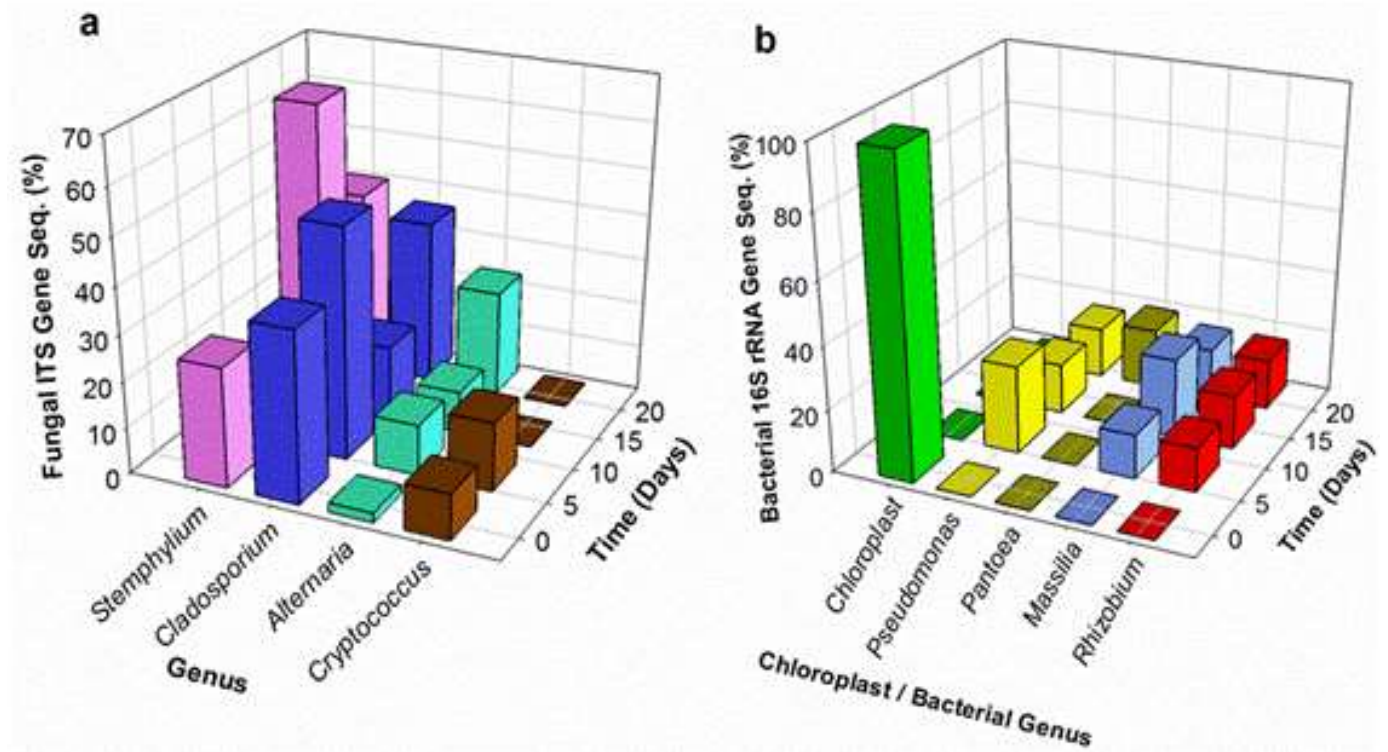

Fig. 2. Fractions of the total fungal (a) and bacterial communities (b) vs. the retting time for the late harvest stems

Notably, no bacteria were recorded on the unretted fresh samples (Fig. 2b). Pseudomonas spp. was dominant during the entire retting period, while Pantoea became dominant during the latter part when cellulose decay was recorded. Rhizobium soli and $M$. aurea were equally dominant during the entire retting period.

\section{Basic Structure and Anatomy of the Developing Hemp Stems}

The cellular structure of the fresh hemp stems from both the early and late harvests before retting (i.e., $0 \mathrm{~d}$ ) are shown in Fig. 3. The overall stem structure remained consistent between the two developmental stages with distinct layers from the central pith towards the outer surface consisting of the innermost woody xylem, cambium, sclerenchymatous bast fibres (inner secondary and outer primary bast fibres), epidermis, and outermost waxy cuticle layer (Figs. 3a and 3d).

The non-degraded nature of the cellular structure in both samples was evident. Living cells (e.g., mesophyll cells) in the epidermis and parenchyma cells among the bast fibres (i.e., with no microbes present within the cell lumen) appeared intact and uncollapsed, and showed a native cellular geometry and the presence of cytoplasmic materials (arrowheads; inset in Figs 3a and 3e), including the plasma membrane (arrows in Figs. 3b and 3e). Distinct differences in the anatomy was apparent in the bast fibre region between the late and early harvest stems, including a low thickness of the primary fibre layers, an increase in the proportion of low-quality secondary fibres, and differences in the anatomy of the primary fibres from the late harvest with an increase in the cell size and lumen. Differences in the parenchyma cells were evident with the fibres arranged into large bundles separated by fewer parenchyma cells in the late harvest compared with the early harvest stems, which still showed developing bast regions. The cuticle layer that acts as a barrier against microorganisms and protects cellular structures from environmental changes (Yeast and Rose 2013) remained intact (Figs. 3c and 3f) and provided a continuous seal to the stem that showed pronounced dermal hairs on the surface of both samples (i.e., trichomes; arrows Figs. 3c and 3f). 


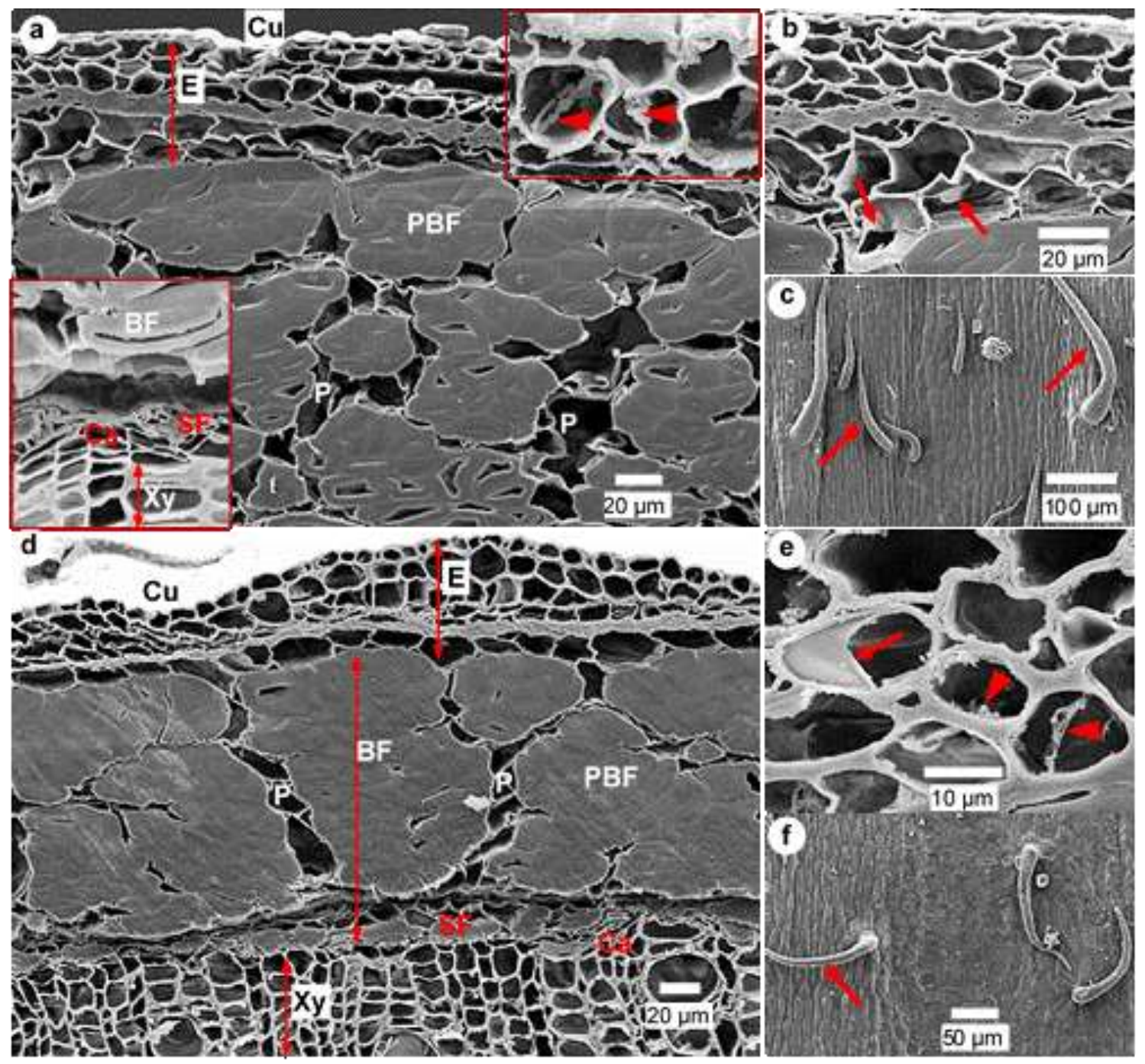

Fig. 3. SEM micrographs of the early (a to $c)$ and late (d to $f$ ) harvest fresh stems: (a, b, $d$, and e) transverse sections showing the intact and layered cellular anatomy with the epidermis and parenchyma cells showing cellular materials (arrows and arrowheads; top right inset in $a$, and $b$ and e), note the poorly developed secondary fibres (SF) in the early harvest (bottom left inset in a) compared with the thick SF layer in the late harvest stem; (c and f) undamaged cuticular stem surfaces with surface trichomes (arrows), note the absence of microbes on the surface and within the stem; $\mathrm{BF}=$ bast fibre region; $\mathrm{Ca}=$ cambium; $\mathrm{Cu}=$ cuticle; $\mathrm{E}=$ epidermis; $\mathrm{P}=$ parenchyma cells; $\mathrm{PBF}=$ primary bast fibres; and $\mathrm{Xy}=\mathrm{xylem}$.

\section{Mechanisms of Field Retting: Micro-morphological and Ultrastructural Aspects}

Field retting was performed directly after the early and late harvests. The retting period after the early harvest (initial: $50 \mathrm{~d}$ ) was relatively warm with a daily average temperature of $19.7{ }^{\circ} \mathrm{C} \pm 3.2^{\circ} \mathrm{C}$ and was dry $(1.1 \mathrm{~mm}$ rain $/ \mathrm{d} \pm 2.6 \mathrm{~mm}$ rain/d). During the last $20 \mathrm{~d}$ of retting after the early harvest and during the whole late harvest retting period (i.e., 7 to 26 September 2013$)$, there was a cool climate $\left(14.2^{\circ} \mathrm{C} \pm 1.7^{\circ} \mathrm{C}\right.$ ) with more humid conditions ( $2.1 \mathrm{~mm} \mathrm{rain} / \mathrm{d} \pm 4.1 \mathrm{~mm}$ rain $/ \mathrm{d})$.

The SEM observations of the retted stems showed evidence of microbial colonization and decay, and various mechanisms and interactions. For example such visual 
evidence, as described below, include: (a) progressive microbial growth initially by fungi over the outer surface and inside the stem; (b) location of fungal colonization within the stem cellular structure (e.g. initially at places with readily available nutrients such as parenchyma, cambium cells); (c) gradual bacterial encroachment attracted by fungal structures and outcompeting fungi with time; (d) intricate and different interactions between fungi and bacteria during retting; (e) aid from fungal hyphae to invading bacteria to reach target substrates; and (f) morphological and ultrastructural characteristics of microbial colonization and resulting degradation of stem structure including cuticle, parenchyma, cortex, cambium, and eventually bast fibres cell walls at later stages.

Because early harvest retting was done over an extended period (50 d), observations on the field-retted late harvest stems were initially discussed, including the periods of $7 \mathrm{~d}$, $14 \mathrm{~d}$, and $20 \mathrm{~d}$. The SEM investigations were performed on both the surface and inside of the stems using the longitudinal tangential (LS) and transverse (TS) sections.

\section{Initial Microbial Colonization and Hemp Cellular Structure during Field Retting}

Figure 4 shows the SEM micrographs of both the surface and internal features of the control samples and retted late harvest stems after $7 \mathrm{~d}$. Little microbial activity was visible on the fresh stem control samples (i.e., $0 \mathrm{~d}$; Fig. 4a). The stems had clean surfaces with surface trichomes protruding from the cuticle with either few or no fungal hyphae or bacteria present (inset and arrow in Fig. 4a).

The LS sections through the outer epidermis close to the cuticle showed living mesophyll cells filled with chloroplasts responsible for the green colour of the fresh stems and no microbes were present (Fig. 4b). Similar results were obtained for the TS sections, which showed no evidence of microbes within the internal cellular structure of the fresh stems (Fig. 3). The field-retted samples however provided remarkable information and evidence for microbial community dynamics and activities depending on the retting period.

For the early retting stages (i.e., 7-d period), sparsely growing fungal mycelia were observed on both the surface (Fig. 4c) and inside of the stems (Fig. 4d), where growth and colonization were concentrated on the outer layers of the cortical cells (arrowheads and inset bottom right in Fig. 4d). Un-collapsed fungal hyphae with smooth surfaces (i.e., indicative of living hyphae) bearing reproductive spores penetrated into the stem structure, even in the early stages (Figs. 4e and 4f). The hyphae grew primarily in the thin-walled parenchyma and/or chlorenchymatous cells located beneath the upper epidermal layer and outer part of the cortex. Dense mycelia were observed in close proximity to the epidermal hairs (Fig. 4g), which acted as penetration sites for the hyphae into the internal cellular structure. The SEM images of the cortical cells (Figs. 4h and 4i) showed hyphae growing within the mesophyll cells containing chloroplasts. The hyphae were closely associated with the chloroplasts (Fig. 4i), which presumably provided an energy source. Hyphae were also frequently observed within the living parenchyma cells in the bast region, which also presumably provided a supply of readily available nutrients (arrows in Fig. 4j). However, hyphae were rarely observed within the outermost hyperdermis layer composed of thickwalled dead cells located just beneath the cuticle (arrows in Fig. 4d). This was attributed to the lack of assimilable nutrients as its main function together with the adjacent cuticle is to act as a protective barrier against mechanical injury, water loss, and infection. 


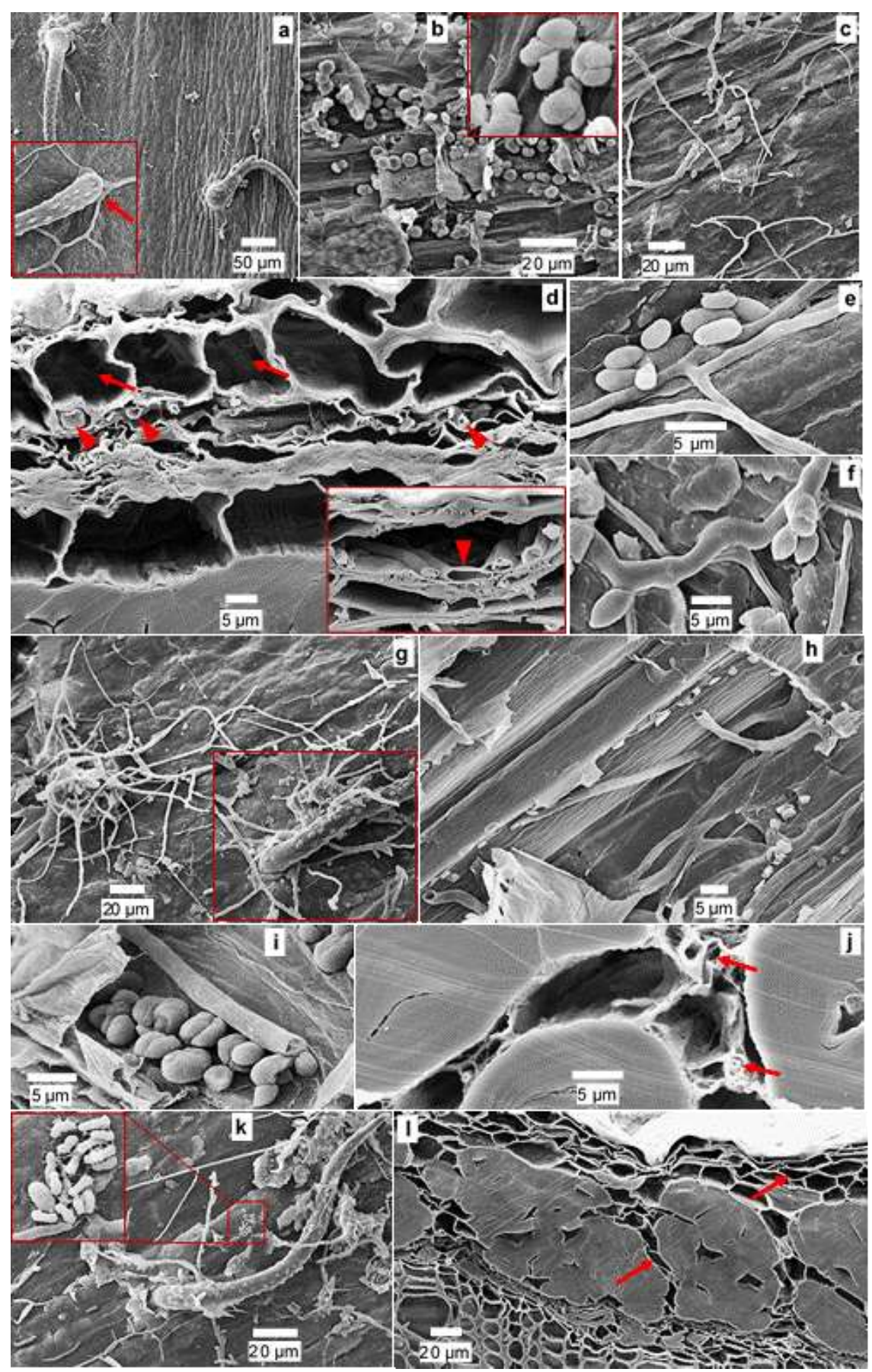

Fig. 4 (previous page). Microbial colonization/activities on both the surface and inside of the late harvest hemp stems after $7 \mathrm{~d}$ of field retting: (a) fresh stem surface and rare fungal hypha close to a trichome (indicated by the arrow in the inset); (b) LS through the living mesophyll cells (outer epidermis) containing chloroplasts; (c) early stage of the fungal colonization on the stem surface with few hyphae; d) stem TS showing the fungal mycelia limited to the outer cortical cells (arrowheads), note the absence of hyphae in the outermost hyperdermis containing dead cells (arrows); (e and f) un-collapsed hyphae with smooth hyphal surfaces containing asexual spores; (g) dense mycelia surrounding trichomes in the early stages of colonization; hyphae colonizing cortical cells containing mesophyll cells (h) and growing in close proximity to chloroplasts that presumably provide readily available nutrients (i); (j) hyphae also colonized the parenchyma cells (arrows) in the bast region; (k) bacteria (top left inset) were rarely observed associated with the mycelia near trichomes; and (I) the overall stem structure and anatomy appeared less damaged, but contained deformed epidermal and parenchyma cells (arrows). 
The low diversity in the fungal community after $7 \mathrm{~d}$ of retting was reflected by the presence of few morphologically different fungal spores, the majority of which were oval in shape with no apparent surface ornamentation (Figs. 4e and 4f). Bacteria were infrequently observed, often close to the epidermal hairs, and were presumably attracted by the presence of dense fungal mycelia, as is shown in Fig. 4k. These results corroborated the results of previous studies, such as Liu et al. (2017a), on samples with a similar age analysed for microbial communities using molecular identification techniques that showed a lower presence and activity of microbes, both in number and percentage. The fungi present were mostly Ascomycetes, while bacteria were less prominent with a low number of clones in the early stages from the phylum proteobacteria. The cellular structure of the hemp stems after one week of retting remained intact with parenchyma cells holding the fibres and fibre bundles together (Fig. 4l), which was more or less similar to that found for the unretted stems. However, the overall stem cellular anatomy appeared less stable, as reflected by the deformed epidermal and parenchyma cells losing their native geometry (arrows in Fig. 4l), which suggested mild attack and degradation of the living parenchyma cells. Decay characteristics in the early stages supported the observations that suggested early dependence of the fungi on readily available nutrients inside of the living cells with less damage to the hemp cellular structure.

\section{Fungal Entry into the Hemp Stem Structure}

The cellular structure of hemp stems is protected from its external surroundings by a waxy cuticle layer, which provides a defensive barrier against microbes and prevents invasion because of its chemically rigid and composite structure. The cuticular layer consists of two major domains: a superimposed outer part containing highly lipophilic materials (i.e., epoxy-like cutin and cuticular wax interspersed with cutin polymers, terpenoids, and propanoids) and an inner layer rich in cutin with embedded polysaccharides that is intimately associated with the underlying epidermis (Samuels et al. 2008; Yeats and Rose 2013; Serrano et al. 2014). The present observations revealed mechanisms (morphological aspects) on how microbes can overcome the rigid outer barrier to enter the nutrient-rich cellular structure.

Figure 5 shows the morphological strategies that filamentous fungi adopted when penetrating into the hemp stems (i.e., samples from $7 \mathrm{~d}$ retted late harvest). During the initial fungal invasion, hyphae used naturally occurring openings in the cuticular waxy layer, such as sites of detached trichomes (Figs. 5a, 5b, and 5c). After trichome detachment, the resulting hole in the surface allowed direct hyphal entry into the upper epidermal cells, which opened a pathway directly into the cell lumen (arrows in Fig. 5a) and provided an opportunity for hyphae to colonize within the intact stem structure. Profuse mycelial growth surrounding the trichome openings (arrows in Fig. 5b) and growth within the stem structure were frequent despite a lack of hyphae over the rest of the cuticle (Figs. 5b and $5 \mathrm{c}$ ). Other natural areas of damage to the cuticular sealing (e.g., cracks and splits) also provided an easy path for direct penetration into the inner stem structure (arrows in Figs. $5 \mathrm{~d}, 5 \mathrm{e}$, and 5f).

Additionally, evidence for direct fungal penetration of the cuticle through hydrostatic or extracellular cutinase activity or both were also apparent (Figs. 5g, 5h, and 5i). This allowed hyphae to advance through the cuticle into the stem, presumably via fungal penetration pegs (Figs. 5h and 5i). Here, severe cuticular degradation occurred via erosion around the hyphae (Figs. $5 \mathrm{~g}$ and $5 \mathrm{~h}$ ). This indicated enzymatic hydrolysis of the 
cuticle in close proximity to the fungal wall. Figures $5 \mathrm{~h}$ and $5 \mathrm{i}$ (arrows) show typical penetration of the cuticle using an infection peg through the cuticle barrier.

However, penetration via infection pegs was rare, and penetration via natural damage in the cuticle appeared to be the principle colonization pathway for the majority of hyphae. The latter is not only a less metabolically intense process, but can also provide a key portal of entry (e.g., large openings from broken trichomes) for any fungal species. Interestingly, findings from the molecular study that showed Cryptococcus and Cladosporium spp. dominated at the beginning of retting (Fig. 2b) were consistent with the results of previous studies (Ribeiro et al. 2015; Liu et al. 2017a). Both fungal species and Stemphylium spp. are known to degrade cuticle layers and produce cutinases (Baker and Bateman 1978; Kolattukudy 1985; Masaki et al. 2005). These microscopy observations provided morphological evidence that supported the conclusion that fungi were early invaders during field retting and they assisted in weakening and disrupting the cuticle barrier during early penetration and colonization. These changes in the stem structure even in early stages should facilitate colonization and accelerate penetration by other fungi or bacteria that lack cutinases, but produce pectinases for degrading pectins in the parenchyma and ML bast fibre walls. For example, S. globuliferum, which possesses a pectinase activity (Wang and Dai 2011; Liu et al. 2017a), was found in the beginning and later stages of retting (Fig. 2b).

Important clues for improvising the natural retting process can thus be drawn from the information gained on the colonization and penetration approaches adopted by early hemp stem-invading filamentous fungi. The findings suggested that the retting period can be reduced by way of mechanical damage to the cuticle of the hemp stem (e.g., removal of epidermal hairs) after cutting and before deposition on the ground. Such a step would overcome most of the issues of bast fibre processing related to time, cost, and environmental aspects.

\section{Microbial Development during the Late Retting Stages (14 d to $20 \mathrm{~d}$ )}

The SEM investigations on the surface of the late harvest stem samples from the late stages of field retting showed a greater and more diverse microbial population (both fungi and bacteria) with intense degrading activities and interactions, and a substantial divergence compared with the early stages. Despite heterogeneity in the spatial distribution (Figs. 6a vs. 6b), highly dense and abundant mycelia were frequently observed to cover the cuticle completely, particularly after $14 \mathrm{~d}$ of retting (Fig. 6b). 


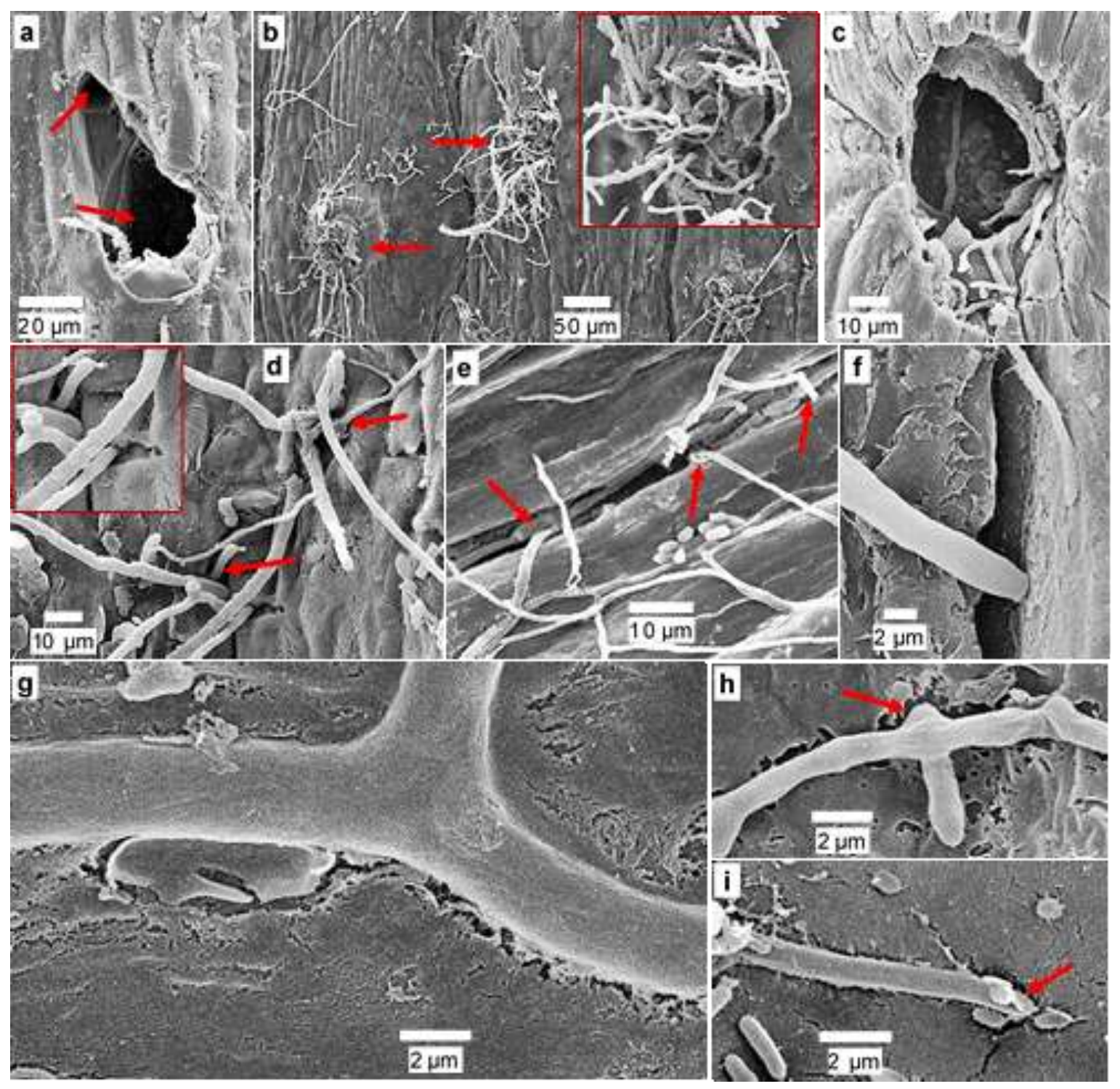

Fig. 5. SEM micrographs showing the fungal strategies for penetrating into the nutrient-rich hemp cellular structure: (a) holes on the cuticle surface of the fresh stem resulting from detached trichomes allowed for a direct path for penetration from the cuticle (arrows show exposed lumens of epidermal cells); (b) dense mycelia at the trichome openings (arrows), note the limited mycelia over the rest of the cuticle surface; (c) trichome opening with fungal hyphae growing into the stem structure; ( $d$ and e) hyphae penetrating into the stem through cracks/splits (arrows), (f) hypha growing towards a crack and penetrating inside of the stem through the crack; and ( $\mathrm{g}, \mathrm{h}$, and i) cuticle degradation around the hyphae $(\mathrm{g}$ and $\mathrm{h})$ and penetration into the stem via infection peg (arrow in $\mathrm{h}$ and i).

Furthermore, not only a variety of morphologically different and greater numbers of fungal spores, but also bacteria were present (Figs. 6c and 6d), which became even more apparent after $20 \mathrm{~d}$. Table 2 provides a summary of the diverse morphological types of fungal spores that existed after $14 \mathrm{~d}$ and $20 \mathrm{~d}$ of retting. This provided evidence for fungal succession and diversity in the community structure during later stages. After $20 \mathrm{~d}$, the cuticle layer was severely decayed, not only because of the action of cutin-degrading fungi, but also by the degrading action of the bacteria (see below). 


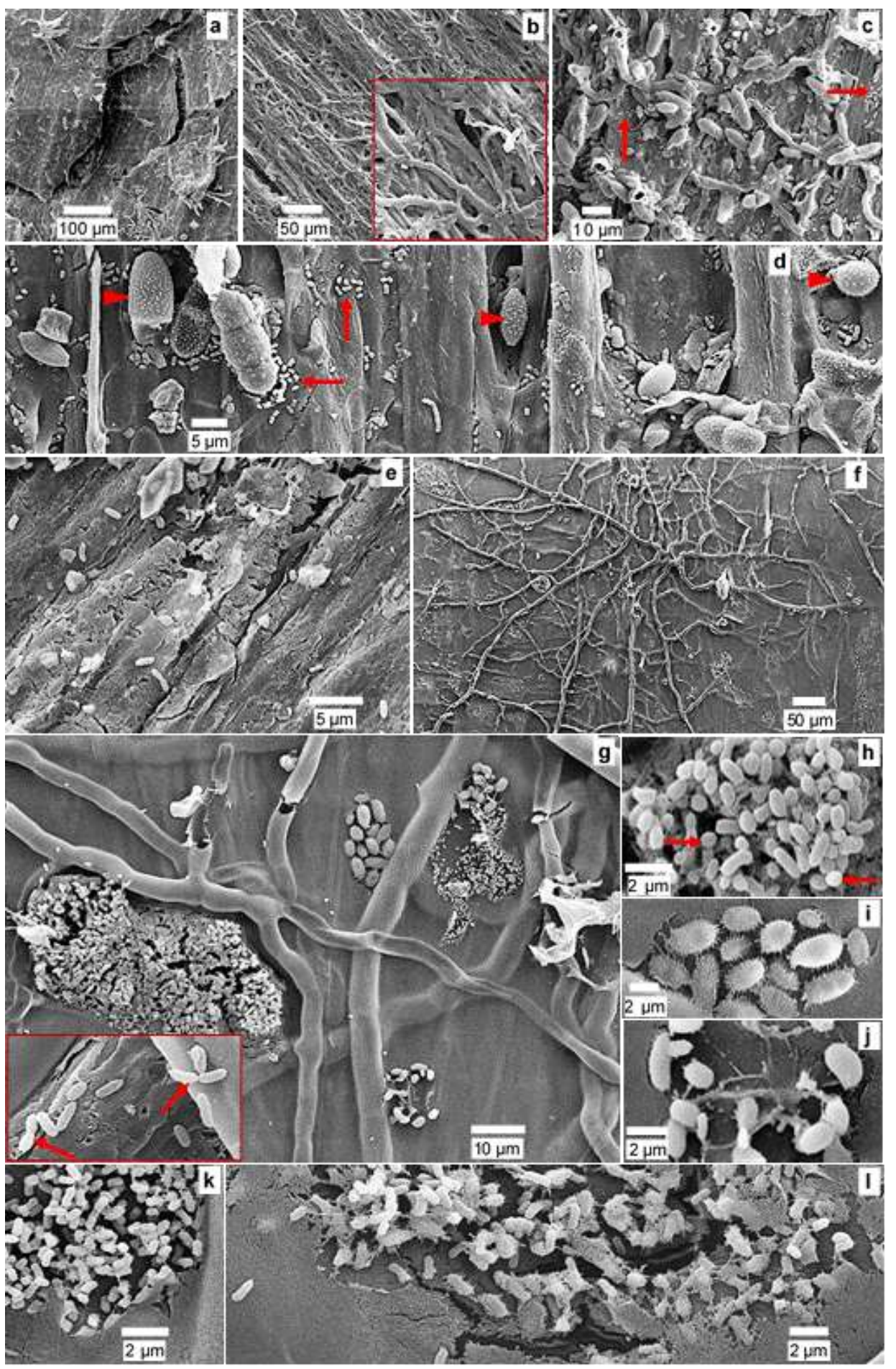

Fig. 6. Surface of the hemp stems after $14 d$ and $20 d$ of late retting: (a) uneven mycelial colonization on the cuticle surface and cracking; (b) dense mycelia covering on the stem surface (inset shows the hyphal density); (c and d) colonization by diverse numbers of morphologically different fungal spores (arrowheads in d) and establishment of bacteria (arrows in c and d) after $20 \mathrm{~d}$ (d); (e) erosion and damage (i.e., holes and cracks) in the cuticular sealing; enhanced bacterial colonization shown at low ( $\mathrm{f}$, distribution) and high magnifications $(\mathrm{g})$ for the bacterial diversity; variations in the bacterial colonies and morphology with rod-shaped, cocci types (arrows in $\mathrm{h}$ ), surface pili containing types (i), and vibrio types (j) present; and ( $\mathrm{k}$ and I) bacteria degraded the cuticle surface with large colonies, which led to severe destruction (I). 
Evidence for degradation and cracks over the cuticle were abundant and visible at places where mycelia were not dense (Fig. 6e). Damage to the cuticular sealing would allow fungi and bacteria to penetrate and colonize inside of the stems, facilitating the degradation and deconstruction of cellular materials. The microscopy observations thus supported the results of the microbial community succession described previously (Figs. $2 \mathrm{a}$ and $2 \mathrm{~b})$.

There was also a parallel growth in the bacterial population that was mostly visible as bacterial colonies or randomly diffused cells (Fig. 6f), or associations with hyphae and fungal spores. The bacterial activity and interaction were found to be diverse, but more pronounced after $20 \mathrm{~d}$ of retting. Like the increase in the fungal diversity in later retting stages, a diverse bacterial population was also apparent (Figs. 6g, 6h, 6i, and 6j). This was discerned via the morphological characteristics of the colony and bacteria size, shape, and surface appendages (e.g., pili).

Figures $6 \mathrm{~h}, 6 \mathrm{i}$, and $6 \mathrm{j}$ show examples where large colonies of bacillus-type bacteria, including diplobacilli (arrows and inset in bottom left of Fig. 6g), of different sizes were common among other bacterial types, such as coccobacillus (arrows in Fig. 6h), some with surface pili (Fig. 6i), and vibrio type (Fig. 6j). This indicated the invasion of different, more aggressive bacterial types during the later retting stages that led to detrimental effects on the bast fibre cell walls by degrading the cellulose.

The SEM observations were consistent with the results from the molecular identification of the bacterial community, where Pantoea spp. only existed after $20 \mathrm{~d}$ (Fig. 2a). Liu et al. (2017a) used samples of a similar age and showed a gradual increase in the $\alpha$-, $\beta$-, and $\gamma$-proteobacteria (e.g., Erwinia and some Pseudomonas spp.) during the late stages, with Bacteroidetes (e.g., Chryseobacterium and Hymenobacter spp.) present only after $20 \mathrm{~d}$ of retting.

Bacteria caused extensive degradation of the cuticle layer, which led to complete destruction (Figs. 6k and 61). The microscopy observations thus provided visual evidence that indicated enzymatic hydrolysis of cutin leading to the deconstruction of the cutin layer by bacteria and thus corroborated the results from the bacterial community analysis. The molecular studies showed Pseudomonas spp. was present during all of the retting periods, including the late stages with considerable numbers, as shown by the frequency percentage (Fig. 2a). Pseudomonas spp. also expresses an extracellular cutinase activity when growing on plant cuticles (Inglis et al. 2011).

\section{Cellular Micro-morphology and Ultrastructure of the Late Harvest Hemp Stems during the Late Retting Stages}

At $14 \mathrm{~d}$ and $20 \mathrm{~d}$, major destruction of the living parenchymatous cells occurred compared with the unretted fresh stems (Figs. 7a and 3). The outer cuticle was damaged (Fig. 7b) with severe destruction of the underlying chlorenchyma cells (Fig. 7c), particularly the parenchyma cells between the bast fibre bundles (asterisk in Fig. 7c). The fibre bundles were mostly separated from the epidermis (double headed arrow in Fig. 7c) and each other, which left extensive voids in the bast regions (asterisks in Fig. 7a and 7c) because of the almost total degradation of the parenchyma cells. 
Table 2. Micrographs of Fungal Spores in the Hemp Stems during Field Retting at Different Time Periods

\begin{tabular}{|c|c|c|c|c|}
\hline Feature & & & \\
\hline
\end{tabular}




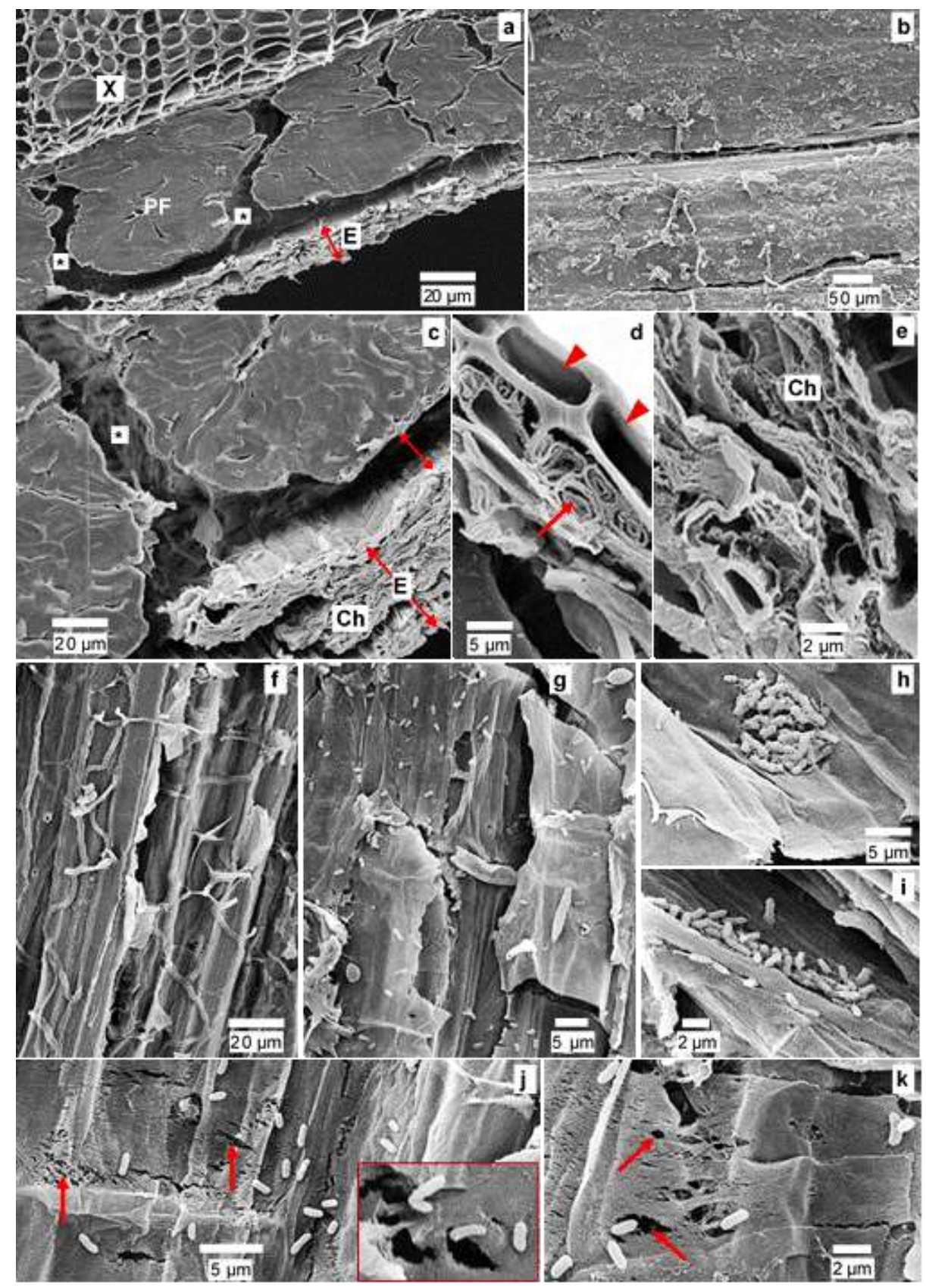

Fig. 7. SEM micrographs showing inside of the retted stems after $14 \mathrm{~d}$ and $20 \mathrm{~d}$ : (a) TS showed damage to the cellular structure, with the parenchyma severely degraded (asterisks) and epidermal cells deformed (E); (b) stem surface with decayed cuticle; (c) parenchyma cells between the primary fibre bundles degraded, which created large spaces (asterisk), and fibre bundles were also separated from the severely decayed epidermis (double-headed arrow); d) the thick-walled hyperdermis (arrowheads) was not colonized in contrast with the underlying denselycolonized chlorenchyma cells (arrow); e) chlorenchyma cells showed extreme decay and dense colonization; (f, $g, h, i, j$, and $k$ ) LS sections through the cortex region with the fungal and bacterial activity inside of the stem structure; there was strong hyphal colonization in the epidermal cells (f) and bacteria attached to the epidermal cell walls $(\mathrm{g})$; ( $\mathrm{h}$ and i) bacterial colonies on the cell walls and degradation (h) and bacteria associated with hyphae (i), note that the degradation of the cortex cell walls created holes (arrows in $\mathrm{j}$ and $\mathrm{k}$ ) that allowed bacteria to migrate inside of the stem structure (inset in $\mathrm{j}$ and $\mathrm{k}$ ); $\mathrm{Ch}=$ chlorenchyma cells; $\mathrm{E}=$ epidermis; $\mathrm{PFB}=$ primary fibre bundles; and $\mathrm{Xy}=\mathrm{xylem}$. 
Parenchyma are enriched cells and therefore can provide nourishment for growing fungi. Figure 7a shows that selective cellular degradation left undamaged bast fibres, which demonstrated the importance of retting before industrial use. Nevertheless, the outermost thick-walled epidermal cell layer (hyperdermis) was seldom colonized (arrowheads in Fig. 7d) in contrast to the underlying chlorenchyma/cortex cells that lacked cell contents after severe decay and extensive fungal colonization (Figs. 7d and 7e). Observations of both the TS and LS sections through the cortex/chlorenchyma regions (Figs. 7f, 7g, 7h, and 7i) provided similar information on colonization. Also, the LS sections showed the presence of bacteria attached to the epidermal cell wall (Figs. $7 \mathrm{~g}$ and $7 \mathrm{~h}$ ) and associated with hyphae living within the cortex (Fig. 7i), which suggested heterogeneity in the distribution and activity.

Despite having thin cell walls in both parenchyma cell types (i.e., those associated with the bast fibres and chlorenchyma cells above the bast fibre region), only parenchyma cells between the bast fibres were totally degraded, while cortex/chlorenchyma cells remained (Fig. 7a; and Fig. 7e). Nevertheless, chlorenchyma cell walls were severely degraded (arrows in Fig. 7j; and inset in Fig. 7j) by simultaneous attack from bacteria and fungi, which produced holes (arrows in Fig. 7k) that provided easy access to the interior of the stem (Figs. $7 \mathrm{j}$ and $7 \mathrm{k}$ ). The difference in attack between the two cell types was explained by variations in the lignification, with the parenchyma cells poorly lignified compared with the epidermal and cortical cells (Liu et al. 2015). The role of lignin in defence against pathogen invasion is well known (Bhuiyan et al. 2009). Because parenchyma cell walls also contain high amounts of pectin (Liu et al. 2015), the SEM observations suggested a strong pectinolytic activity from the majority of microbes at this retting stage that led to the advanced and complete destruction of cells.

The endophytic fungus $S$. globuliferum that dominated the late retting stages (Fig. 2b) possesses both pectinolytic and cellulase activities (Wang and Dai 2011), which explains its late dominance and agreed with the SEM observations that showed severe degradation of the parenchyma and epidermal cell walls. Similarly, the presence of Cladosporium spp., which is also known to produce pectin lyases and cellulases (Brown and Sharma 1984), was particularly high after $20 \mathrm{~d}$ (Fig. 2b) and likely contributed to the severe decay of pectin-rich cells. Pseudomonas spp. was identified during all of the retting periods (Fig. 2a) and is also known as an important pectin decomposer during retting (Rosemberg 1965). Thus, both fungi and bacteria were likely involved in cell wall degradation, as seen in Figs. $7 \mathrm{j}$ and $7 \mathrm{k}$. The results from the microbial community and SEM analyses agreed with the mass and pectin losses of the samples, where the rate of reduction was higher in the late retting stage (Fig. 1). The results were also consistent with changes in the pectinolytic and glucanase activities reported previously using enzyme assays during a parallel study on hemp retting (Liu et al. 2017a).

In contrast, after $14 \mathrm{~d}$ and $20 \mathrm{~d}$, the bast fibres were generally intact with thick cellulose-rich cell walls (Fig. 8a). Some minor fungal hyphae colonization of the fibre lumina occurred (arrows in Fig. 8b), although when adjacent parenchyma cells were present, they were heavily colonized (arrowheads in Fig. 8b). The fibre morphology strongly affected the characteristics of the fungal colonization and decay intensity with an apparent positive correlation between the size of the fibre lumen and both the size of the hyphae and density of colonization (Figs. 8c and 8d) and degradation (Fig. 8e). The fungal hyphae also adhered to the outermost layer of the bast fibre cell walls in the ML regions bonded to adjacent parenchyma cells (arrows in Figs. 8f and 8g). This indicated a fungal pectinolytic activity on pectin-rich cell wall layers and ML degradation of the fibre wall, 
which led to fibre separation (arrow in Fig. 8h). Bacteria were also observed inside of the fibre lumens, but were most often with hyphae (arrows in Fig. 8i). This suggested that mycelium-assisted bacterial displacement from the surface regions into the bast region. Microbial decay and interactions during $14 \mathrm{~d}$ to $20 \mathrm{~d}$ of field retting showed: a) the progressive colonization and attack by filamentous fungi, followed by bacteria; and $b$ ) that the initial microbial invasion was likely attracted and supported by easily accessible food materials within the cellular structure of the hemp stem, and influenced by the anatomy and morphology.

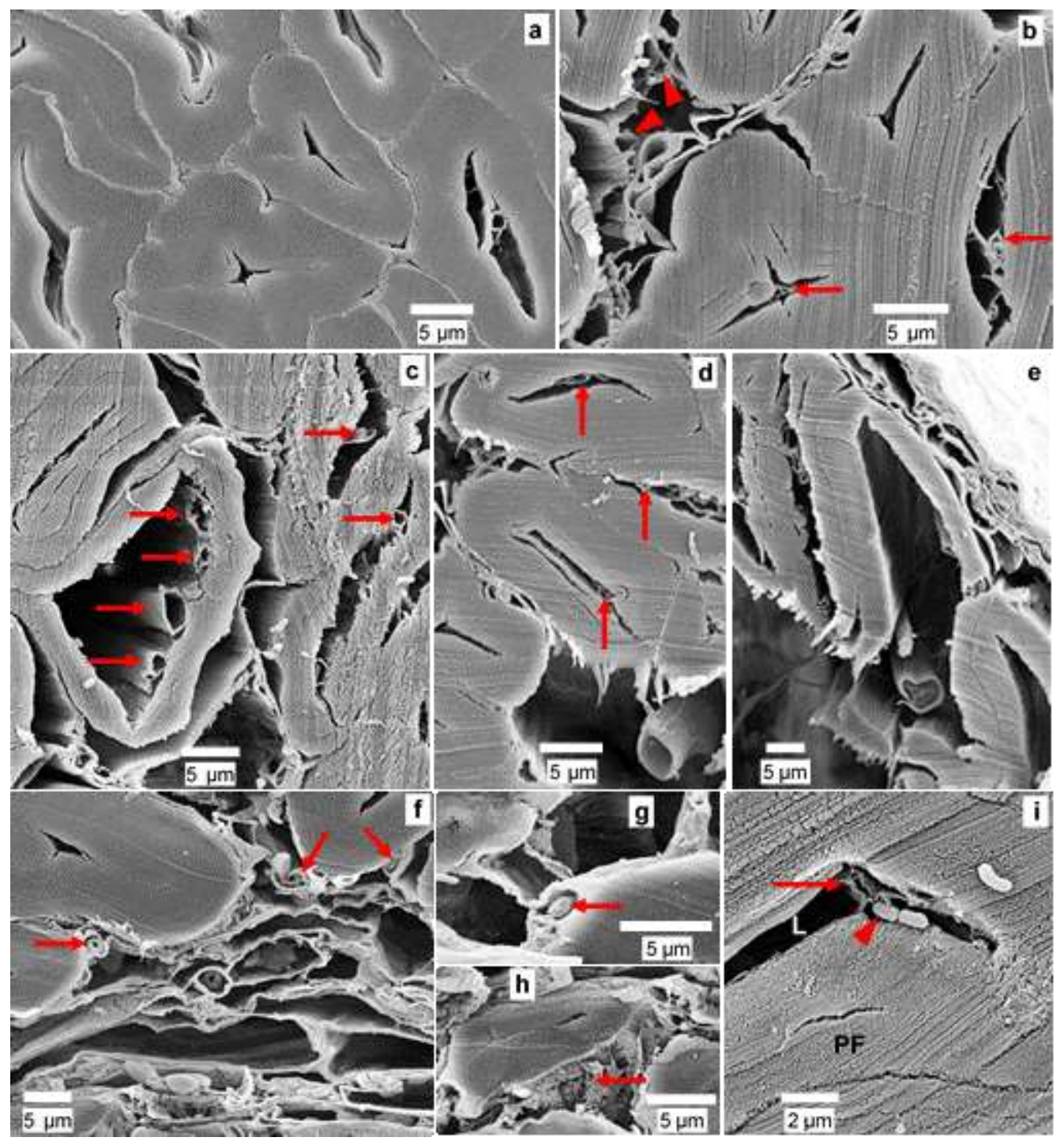

Fig. 8. Bast fibre structure after $14 \mathrm{~d}$ and $20 \mathrm{~d}$ : (a) view of the bast fibres with intact thick cell walls and some colonization within the cell lumens; (b) minor colonization inside of the lumina of the primary fibres (arrows), while the adjacent parenchyma cells were severely colonized and degraded (arrowheads); fibres with larger cell lumina showed greater hyphal growth and colonization and vice versa (arrows in $\mathrm{c}$ and d); fibres with large lumens showed severe decay (e); (f) fungi were attached to the ML of the fibre walls (arrows); (g) example of hyphal attachment to the $\mathrm{ML}$ (arrow) and associated degradation; (h) the $\mathrm{ML}$ of the fibre cell walls was selectively degraded (arrow), which allowed bast fibre separation; (i) bacteria (arrowhead) associated with hyphal cell walls (arrow) and colonizing inside of the fibre cell lumens; and PF = primary fibres. 


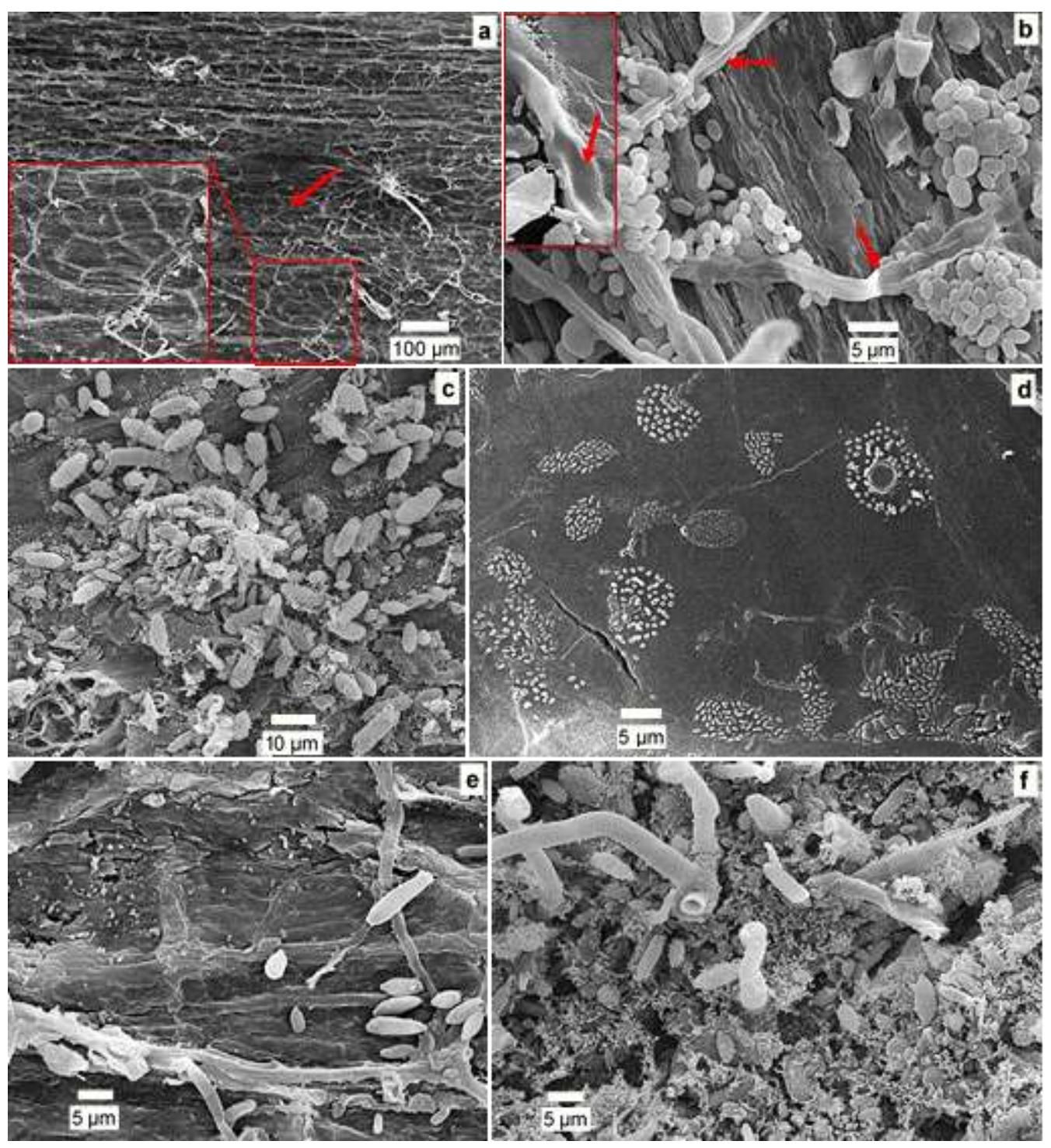

Fig. 9. Stem surfaces after $50 \mathrm{~d}$ and $60 \mathrm{~d}$ of prolonged retting, which highlighted the dominant role of the bacteria: (a) thin fungal mycelia web over the stem surface with the cuticle appearing transparent (arrow) and thus, the underlying network of epidermal cells were visible (inset); (b) collapsed dead hyphae (arrows) and numerous fungal spores; (c) enormous numbers of morphologically different fungal spores with an interconnected spore film on the surface; (d) dominant presence with morphologically diverse bacteria colonies (size/shape) spread across the stem surfaces; (e) bacteria were randomly distributed across the stem surfaces and not concentrated in the colonies (as is seen in d); and ( $f$ ) dense bacterial biofilm on the stem surface.

\section{Long Retting Periods of the Early Harvested Stems and Bacterial-fungal Interactions}

The early harvest stems were subject to retting times of $50 \mathrm{~d}$ and $60 \mathrm{~d}$, where the weather conditions were different from those of late harvest retting (i.e., warmer with less rainfall) and thus were expected to have different microbial activities. The SEM investigations of the early harvest hemp samples from the long retting periods showed that the bacteria played a more dominant role compared with the short retting times. The stem surfaces showed sparsely distributed fungal mycelia compared with that of the 20-d retting (Fig. 9a), and the pellucid epidermal cells showed an interconnected network structure 
(arrow and inset in Fig. 9a). Fungi most often appeared in a non-living state, as reflected by the collapsed hyphae (inset and arrows in Fig. 9b) and/or only spores with no or few hyphae (Fig. 9c). These observations suggested that the mycelia reached the end of their life-cycle with numerous fruiting bodies on the stem surfaces (Figs. 9b and 9c). In contrast, morphologically different bacterial colonies (i.e., in size and shape) existed over the stem cuticle (Fig. 9d), including randomly dispersed bacterial cells (Fig. 9e) or a dense bacterial overlay similar to biofilms (Fig. 9f). This emphasized a considerable diversity in the bacterial community that dominated at this stage, which signified moderate to aggressive bacterial activities and/or bacterial-fungal interspecies associations, as described below.

\section{SEM Observations of Bacterial-fungal Interactions and Bacterial Mycophagy}

Long-standing fungal mycelia on the retted hemp surfaces (i.e., > $50 \mathrm{~d}$ old) showed frequently associated bacteria and colonizing hyphae (Fig. 10a), including fruiting bodies, which indicated BFIs (Fig. 10). These observations suggested that the bacteria were likely deriving nutrients from these hyphal structures, at least at the beginning of colonization, which was pronounced during prolonged field retting. Although BFIs are known to exist in different contexts in nature (Frey-Klett et al. 2011), it seemed here that this interspecies association can provide invading bacteria an exclusive source of nutrients from fungal mycelia (i.e., bacterial mycophagy). Nutrients were likely obtained by bacteria within a BFI on the hemp stem surfaces, as reported for other ecosystems, via: a) fungal exudates (i.e., low molecular weight metabolites like organic and amino acids, storage sugars (e.g., trehalose), and polyols (e.g., mannitol)); b) sugars and other break-down products from the hemp stem structure produced by fungal extracellular enzymes ( $\mathrm{a}$ and $\mathrm{b}$ are known as extracellular biotrophy); c) through endosymbiosis, where the endo-fungal bacteria reside within the fungal cytosol, i.e., endocellular biotrophy; and d) by direct lysis of the fungal cells (living or dead) by bacteria, which is known as extracellular necrotrophy (de Boer et al. 2005; Leveau and Preston 2008; Frey-Klett et al. 2011). The latter scenario seemed more evident with long retting times, as detailed by the SEM investigations (Fig. 10).

For example, bacteria were frequently associated with exudate materials surrounding the hyphae, which reflected an extracellular biotrophic activity (Figs. 10a and 10b), while densely colonized dead hyphae (Fig. 10c) and fungal spores (Fig. 10d) were more common, which represented fungivore behaviour belonging to necrotrophy (Figs. 10c and 10d). These observations also indicated bacterial lysis of the hyphae (arrows in Figs. 10e and 10f) and spores (inset and arrowhead in Fig. 10e), leading to decomposition (i.e., extracellular necrotrophy). Moreover, the observations implied the existence of bacterialfungal endosymbiosis interactions (Figs. $10 \mathrm{~g}, 10 \mathrm{~h}, 10 \mathrm{i}$, and $10 \mathrm{j}$ ). This is a strategy used by bacteria during endocellular biotrophy to obtain nutrients (Leveau and Preston 2008).

Figure $10 \mathrm{~g}$ shows living fungi, as reflected by the tubular hyphae, and Fig. 10h shows bacteria attached via pili to the fungal wall with activities consistent with endosymbiosis, as reported by Moebius et al. (2014). The surface of the living fungi cell walls was generally smooth when observed with SEM (Fig. 10g). However, during the course of bacterial invasion and penetration of hyphae, the fungi cell walls appeared coarse with the presence of marks (troughs) that indicated bacterial intrusion into the surface (Figs. 10i and 10j). As described previously (Moebius et al. 2014), the penetration process shown here was initiated by initial adhesion to the host surface by bacterial fibrillar structures (e.g., fimbria or pili) (inset and arrows in Fig. 10h). 


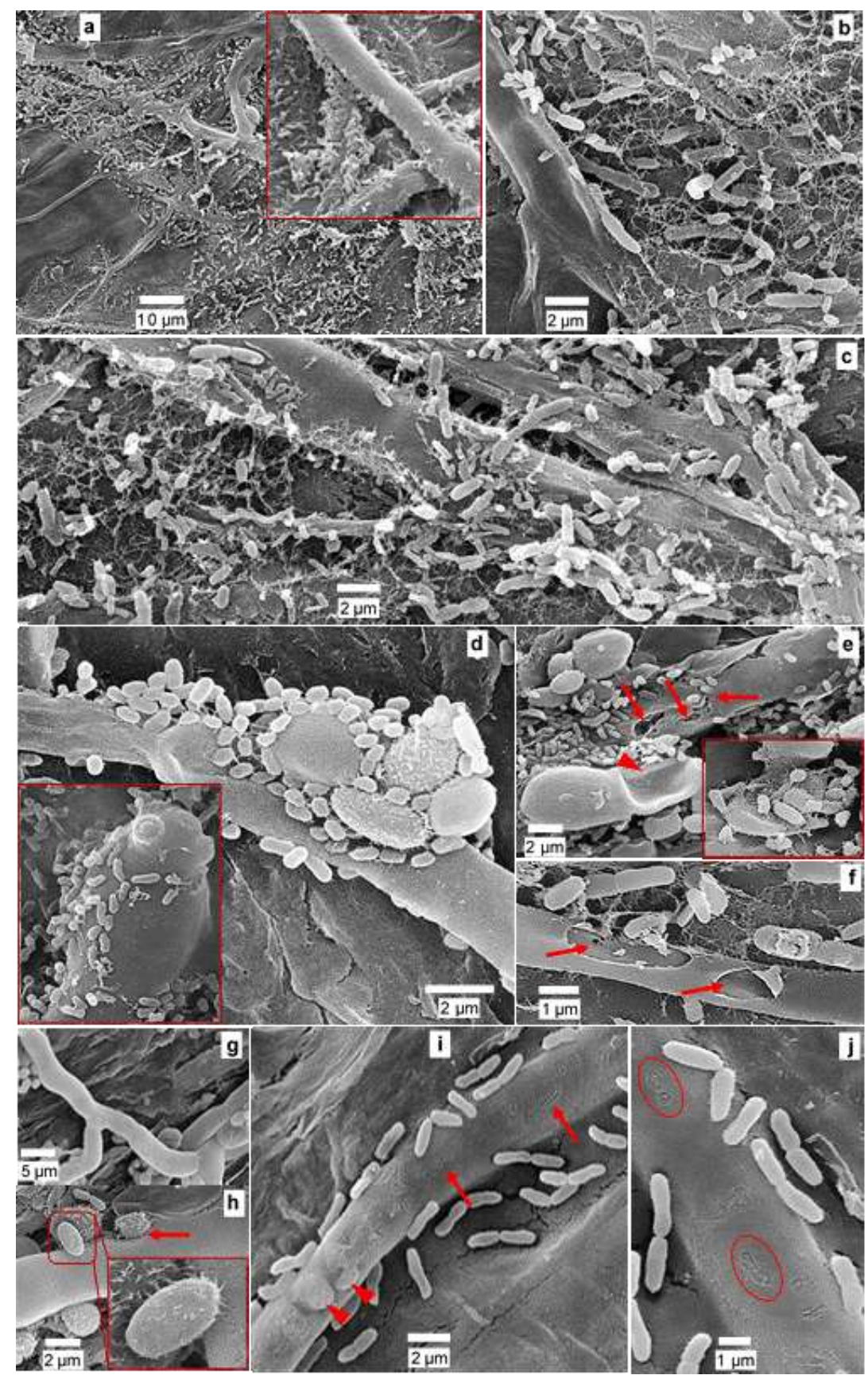

Fig. 10. SEM micrographs showing the BFIs and bacterial mycophagy with prolonged retting: (a and b) bacteria was closely associated with the hyphae (living/dead), which suggested dependence on fungal-derived substrates, like slime materials (thin thread-like matrix materials seen in b) surrounding the hyphae and (b) the phenomenon of extracellular biotrophy of bacterial mycophagy; (c, d, e, and f) bacteria directly associated with the hyphae (c) and spores (d), which led to their degradation/lysis (arrows in e and f; arrowhead in e and inset) and reflected phenotypic behaviour of mycophagy known as extracellular necrotrophy; (g) living hypha with a characteristic tubular shape and smooth hyphal surface; ( $h$, i, and j) endocellular biotrophic behaviour of bacteria for nutrients, where infection from the initial active attachment onto the hyphal surface occurred via bacterial pili (arrows and inset in h); subsequent processes ( $\mathrm{i}$ and $\mathrm{j}$ ) included merging and fusion of the bacterial and hyphal cell walls and the intrusion of bacteria into the hyphae (arrowheads in i); fusion sites reflecting the shape of the bacteria (cocci and rodshaped; arrows in i and circles in j) were visible on the hyphal surfaces ( $I$ and $j)$; and no visible signs of hyphal lysis or wall degradation were apparent. 
Figures $10 \mathrm{i}$ and $10 \mathrm{j}$ show evidence of bacterial fusion and subsequent entry into the hypha walls, including: a) swollen sites on the hyphal wall because of localized chitinolytic activity by bacteria for local dissolution and loosening of the fungal wall during the intrusion process (arrowheads in Fig. 10i); and b) fusion sites, where bacteria entered the fungal cells by fusion with the hyphae walls (note the troughs on the hypha surface that reflected the shape of the bacteria; arrows in Fig. 10i and circles in Fig. 10j).

Hyphal cell wall lysis and disintegration around the bacterial intrusion sites were not evident, but implied a "melting-like" gentle penetration process without damaging the surrounding hyphae wall. Moebius et al. (2014) revealed the mechanism involved during such an active invasion by bacteria and identified involvement of a commonly known bacterial secretion system (e.g., T2SS) required for the formation of endosymbiosis. The system involves attachment and infection during a BFI and release of chitinolytic enzymes (e.g., chitinase and chitosanase), including chitin-binding proteins that help to locally soften the fungal cell wall for bacterial intrusion without loss of the fungal wall integrity surrounding the intrusion sites, as was shown here. Moebius et al. (2014) reported this mechanism from a laboratory study, while a similar penetration procedure occurring in nature during field retting was found in this study.

\section{BFI and Fungal Highways}

Bacteria were often observed attached in an organized manner to hyphal surfaces resembling a motorway queue (Figs. 11a, 11b, and 11c) and not colonized locally or densely, as described above. This presumably reflected the bacterial motility and their ability to use hyphal surfaces as a path to migrate in search of new substrates and novel microhabitats for colonization. Bacteria are known to move and disperse (e.g., swimming and swarming) along fungal mycelia driven by their intrinsic motility through continuous liquid (water) films surrounding hydrophilic hyphae (Simon et al. 2015). This phenomenon is known as a fungal highway (Kohlmeier et al. 2005). The increase in the fungal community over the hemp stem surface and greater network of mycelia inside of the hemp structure during the late stages of retting provide a continuous fungal highway for bacteria to migrate from the outside to the inside of stems. This partly explained the enhanced bacterial population inside of the hemp stems observed only after prolonged retting; the fungal community dynamics with time generated a better microsphere for bacteria both on the surface and inside of the stems that coincided with changes in the bacterial community and abundance.

The detailed SEM analysis indicated that prolonged hemp retting (i.e., > $50 \mathrm{~d}$ ) attracts greater bacterial communities and promotes their growth and activities, which were further stimulated by aging fungal mycelia enriched with nutrients. A similar scenario has been reported in nature during leaf-litter decomposition (Kirby 2005; Schneider et al. 2012). Schneider et al. (2012) reported fungi as the primary producers of extracellular hydrolytic enzymes in leaf-litter decomposer communities, especially during early stages of colonization. It was further stated that microbial succession is influenced by the litter nutrient content via a higher abundance and activity of extracellular enzymes with a greater bacterial activity in later phases of litter decomposition.

During prolonged retting, bacteria also demonstrated an enhanced cutinolytic activity that led to degradation and deconstruction of the hemp cuticle (Figs. 11d, 11e, 11f, $11 \mathrm{~g}$, and 11h). Inglis et al. (2011) reported that many bacteria isolated from mixed-plant composts exhibit a greater cutinase activity when grown with plant cuticles. 


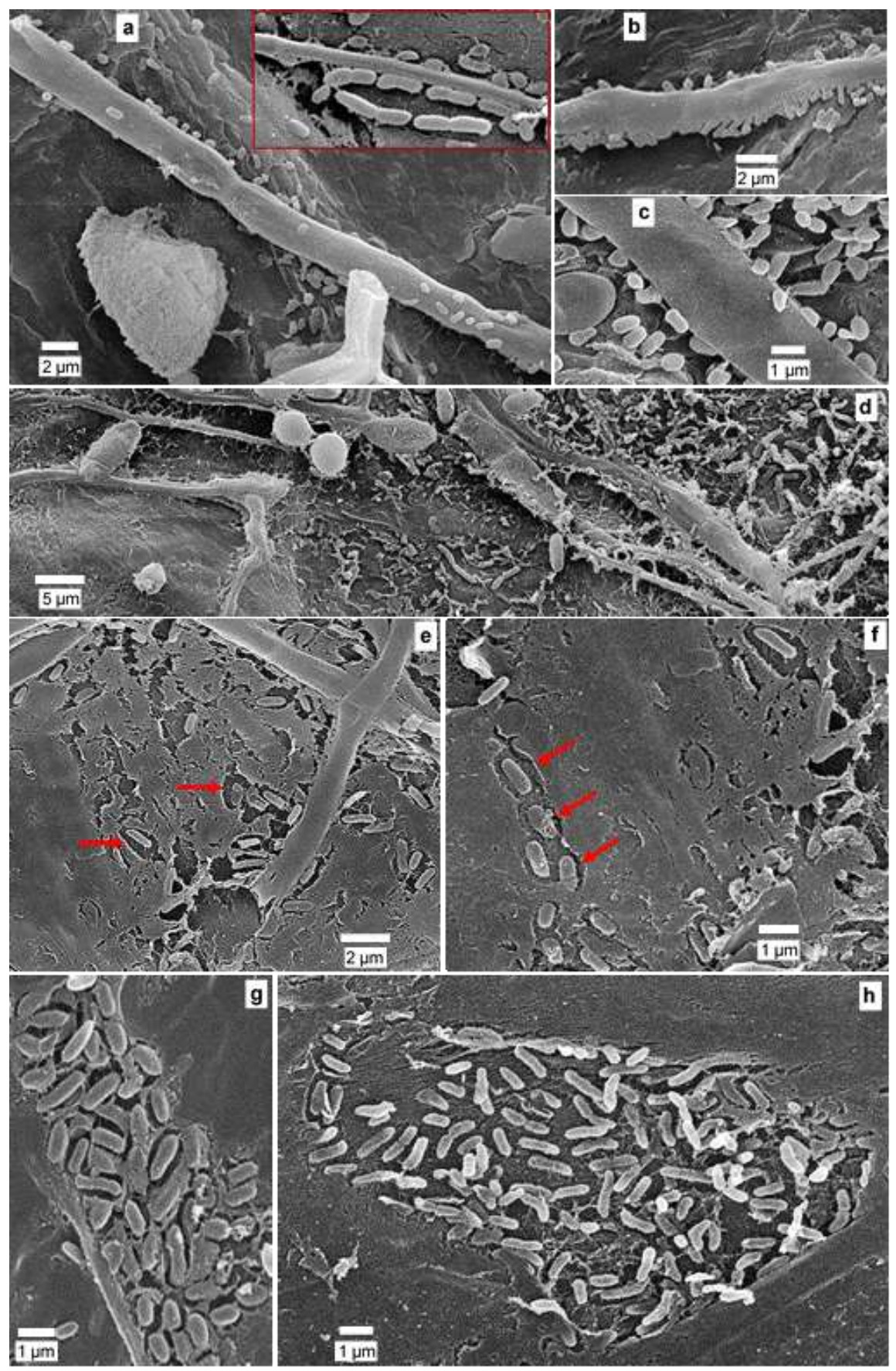

Fig. 11. Fungal highways ( $a, b$, and $c$ ) and bacterial migration on and within the hemp stems and evidence of enhanced cutinolytic activity by the bacteria (d, e, f, g, and $h) ;(a, b$, and c) sections from the hemp stem surfaces showed characteristic bacteria attachment in queues on the hyphal surfaces; the bacterial organization appeared only on the hyphal surfaces and was different from that on the cuticle and in other colony and biofilm associations; no visible signs of hyphal degradation were apparent and provided visual evidence for bacterial migration by fungal highways; (d) bacteria heavily colonized the aging hyphae and their immediate surroundings, which suggested a rich supply of nutrients derived from the fungal origin; (e) bacteria degraded the hemp stem cuticle close to a fungal hyphae, and cuticle destruction resulted from the initial superficial erosion around the individual bacteria (arrows); (f, g, and h) stem surfaces showed cuticle degradation and severe destruction by bacteria with typical erosion troughs around the bacteria (arrows in $f$ ); and the erosion troughs tended to combine with each other ( $f$ and $g$ ), which led to severe cuticle erosion and destruction by large bacterial colonies (h). 
Cuticles in the vicinity of fungal mycelia were severely decayed by cutinolytic bacteria, with the attack characterized by extensive superficial erosion of the cuticle layer (Figs. 11d and 11e). The activity was most likely influenced by bacterial lysing of the hyphae (Fig. 11e), with cuticle destruction around the hyphae indicating the impact of BFIs on cuticle decay. Erosion attack was mostly done by rod-shaped bacteria (i.e., bacillus type) with the formation of characteristic troughs around the bacteria (arrows in Figs. 11e and 11f). During severe attack and involvement of large numbers of bacteria (Fig. 11g), erosion troughs around bacteria were united to form large eroded areas, which led to severe cuticle destruction (Figs. 11g and 11h). The $\gamma$-proteobacteria Pseudomonas spp. are well known producers of extracellular cutinase with a high activity on plant cuticles (Sebastian et al. 1987; Inglis et al. 2011), including Pantoea from the same phylum. The present observation provided evidence that supported the occurrence of enzymatic hydrolysis of the hemp cuticle by cutinolytic bacteria. The bacterial community succession also confirmed the presence of Pseudomonas, and in particular Pantoea was detected only during late phases of retting (Fig. 2a), which was consistent with the SEM observations.

\section{Changes in the Hemp Structure and Bast Fibres during Prolonged Retting}

After $50 \mathrm{~d}$ of retting, the overall microstructure of the hemp appeared similar to that after 20 d. However, the stem was severely affected and disintegrated in the epidermal, cambia, and bast regions (Fig. 12a) through the action of BFIs with some destruction of the bast fibres. Epidermal (Fig. 12b) and cambial cells (Fig. 12c) were extensively colonized and degraded with bacteria that represented the predominant group (inset in Fig. 12 b, and Fig. 12c). Voids between the adjacent tissue layers were clearly visible between the remaining epidermis and underlying bast fibres (double headed arrow in Fig. 12a), and the cambium zone above the core xylem (double headed arrow in Fig. 12d). Also, parenchyma cells in the bast region were completely degraded and absent (Fig. 12a), which led to a loss in the structural integrity between the bast fibre bundles. As a result, large voids within the bast region were observed in the TS sections (arrows in Fig. 12a) that separated the fibre bundles and single fibres, which was presumably aggravated during preparation of the stems for microscopy. This micro-structural investigation elucidated the outcome of retting, where the major objective was to easily remove the bast fibres/fibre bundles with as little damage as possible for use in biocomposites.

Observation of the TS sections provided details of the colonization and BFIs present inside of the hemp stems, including implications on the hemp micro/ultrastructure during prolonged retting. Bacterial establishment and activities, and interactions both inside of and on the stem outer surfaces emphasized the importance of bacteria as major players in prolonged retting. Bacteria were observed inside of the lumina of almost all of the cell types, including the epidermis (inset in Fig. 12b), parenchyma (Fig. 12e), cambium (Fig. 12f), and xylem (Fig. 12g), which indicated extended colonization and distribution of the microbes deep into the stem structure, including the bast fibres (Figs. 12h, 12i, and 12j). Figure $12 \mathrm{~h}$ shows fibre cell walls in the presence of both bacteria (arrowheads) and fungi (arrows) inside of the cell lumen, with the degraded inner walls indicating collective attack, even on the thick-walled bast fibres. In contrast to the surface observations at this stage, fungi with tubular hyphae were present inside of the lumina of all of the cell types, including the bast fibres and xylem cells. The observations showed hyphae were attached to the outermost layer of the bast fibres adjacent to the parenchyma cells (inset arrows in Fig. 12i) with decay of the ML of the bast fibres (i.e., pectins and hemicellulose), which followed depletion of the nutrients and total decay of the parenchyma cells. 


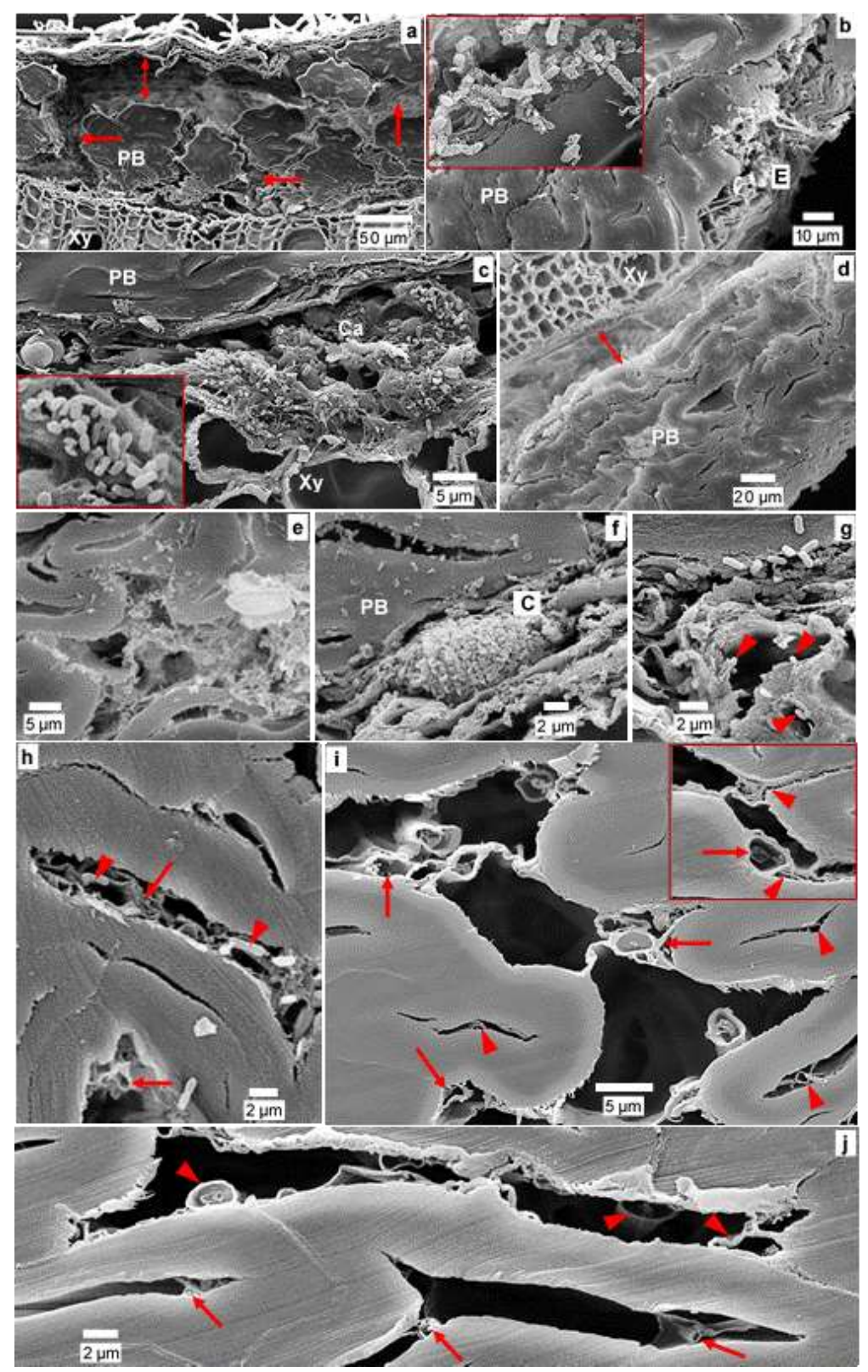

Fig. 12. Stem TS sections and hemp structure after $50 \mathrm{~d}$ of prolonged retting: (a) the stem anatomy was severely affected with the bast fibres and bundles disintegrated from each other (arrows) and the rest of the cellular structure (i.e., from epidermis (double-headed arrow) and cambium leaving large voids); the parenchyma was degraded in the bast regions, which allowed fibre bundles to disintegrate from each other (arrows); (b) the stem epidermal regions were heavily colonized by the bacteria (inset) and severely degraded; (c) living cells from the cambium zone showed intense colonization and degradation by the bacteria (inset); (d) complete degradation of the cambium led to separation of the bast fibre region from the core xylem (double-headed arrow); (e) parenchyma in the bast region showed heavy colonization by the bacteria; (f) the cambium cells were heavily colonized and decayed by the bacteria; ( $g$ ) the xylem cells were colonized and degraded by the bacteria (arrowheads); (h) both bacteria (arrowheads) and fungi (arrow) colonized inside of the lumina of the bast fibres and collectively attacked the thick cell walls of the fibres; ( $i$ and $j$ ) the hyphae started to degrade the thick-walled bast fibres both from the lumen (arrowheads in $\mathrm{i}$ and arrows in $\mathrm{j}$ ) and ML of the bast fibres (arrows in $\mathrm{i}$ and arrowheads in j), note the impact of the hyphal attack on the ML, where loosening and cracking of the layer led to disintegration from the remainder of the fibre wall (arrow and arrowheads in the inset in i); $\mathrm{Ca}=$ cambium; $\mathrm{E}=$ epidermis; $\mathrm{PBF}=$ primary bast fibres; and $\mathrm{Xy}=\mathrm{xylem}$. 
The impact on the compound middle lamella (CML) region close to the hyphae was demonstrated by the loosening of the outermost wall layer from the rest of the fibre (inset and arrowheads in Fig. 12i). Activity inside of the stem structure was indicated where hyphae penetrated through the fibre cell wall and resided inside of the cell lumen (arrowheads in Fig. 12i). The results suggested that fungi had already initiated degradation of the thick-walled bast fibres from both the outside (arrowheads in Fig. 12j) and inside (arrows in Fig. 12j) of the fibres.

Similar information was obtained when analysing the LS sections through the epidermal-bast regions (Fig. 13). Colonization by fungi hyphae, especially of the palisade cells containing chloroplasts, was frequent (Figs. 13a, 13b, and 13c). The hyphae grew in close proximity to cytoplasmic materials (i.e., chloroplasts) (Fig. 13c, and arrow in Fig. 13d), which allowed substrate hydrolysis through fungal exoenzymes. Their hydrolytic activity was visually evident with high magnification imaging that confirmed the presence of fungal extracellular slimy substances over chloroplasts (arrowhead and inset in Fig. 13d) and the resulting degradation of organelles (arrows in Fig. 13e). Abundant bacteria were present in the epidermal (arrow in Fig 13f, and Fig. 13g), parenchyma, and fibre cells (Fig. 13h), and most of the bacteria displayed intrinsic motility (e.g., flagella and pili; Figs. 13g and 13i), which supported the existence of fungal highways to reach the inner cells of the hemp stem structure. At this stage, bacteria collectively contributed to severe cellular degradation of the entire parenchyma cells (Fig. 13g), cell walls, and cytoplasmic materials (Fig. 13i), and caused localized degradation of the outer layers of the fibre cell walls (Figs. $13 \mathrm{~h}$ and $13 \mathrm{j}$ ). The microscopy analysis therefore provided visual evidence that supported the presence of intense fungal/bacterial activity inside of the stems extending towards the bast fibres and leading to a loss in the fibre quality.

\section{Changes in the Morphological Ultrastructure of the Bast Fibre Cell Walls}

Prolonged retting had serious consequences on the hemp cellular structure, and considerable deterioration of the morphological structure of the thick-walled bast fibres was revealed. Ultrastructural modification and damage of the bast fibre walls affected all of the major layers. Loosening and partial degradation of the outermost CML occurred, which caused its delamination (arrows in Fig. 14a) and explained the defibration of the single fibres after retting. Decay also extended into the innermost thin layer of the fibres surrounding the cell lumen by microbial attack from the lumen side. Figure $14 \mathrm{~b}$ shows an example of a hypha within a bast fibre lumen attached to the innermost layer of the fibre wall that caused its delamination (arrowhead in Fig 14b) and decay of the innermost surface of the wall (arrows in Figs. 14b and 14c).

The most prominent and detrimental effect of prolonged retting was the loosening of the cell wall ultrastructure of the dominant secondary S2 layer of the bast fibres, which led to its disintegration and delamination. Crack development was observed between layers within the thick S2 layer, and typical intrawall fractures following the concentric lamellar structure of the S2 secondary wall were apparent (arrows in Figs. 14d and 14e). Presumably this resulted from weakening and partial degradation of the thin transition concentric lamellae present between the thick layers, as was shown previously by Thygesen et al. (2013), who observed a similar ultrastructural effect with fungal defibration of hemp fibres using the mutant white rot fungus Phlebia radiata Cel 26, a preferential degrader towards lignin/pectin and lacking cellulases. 


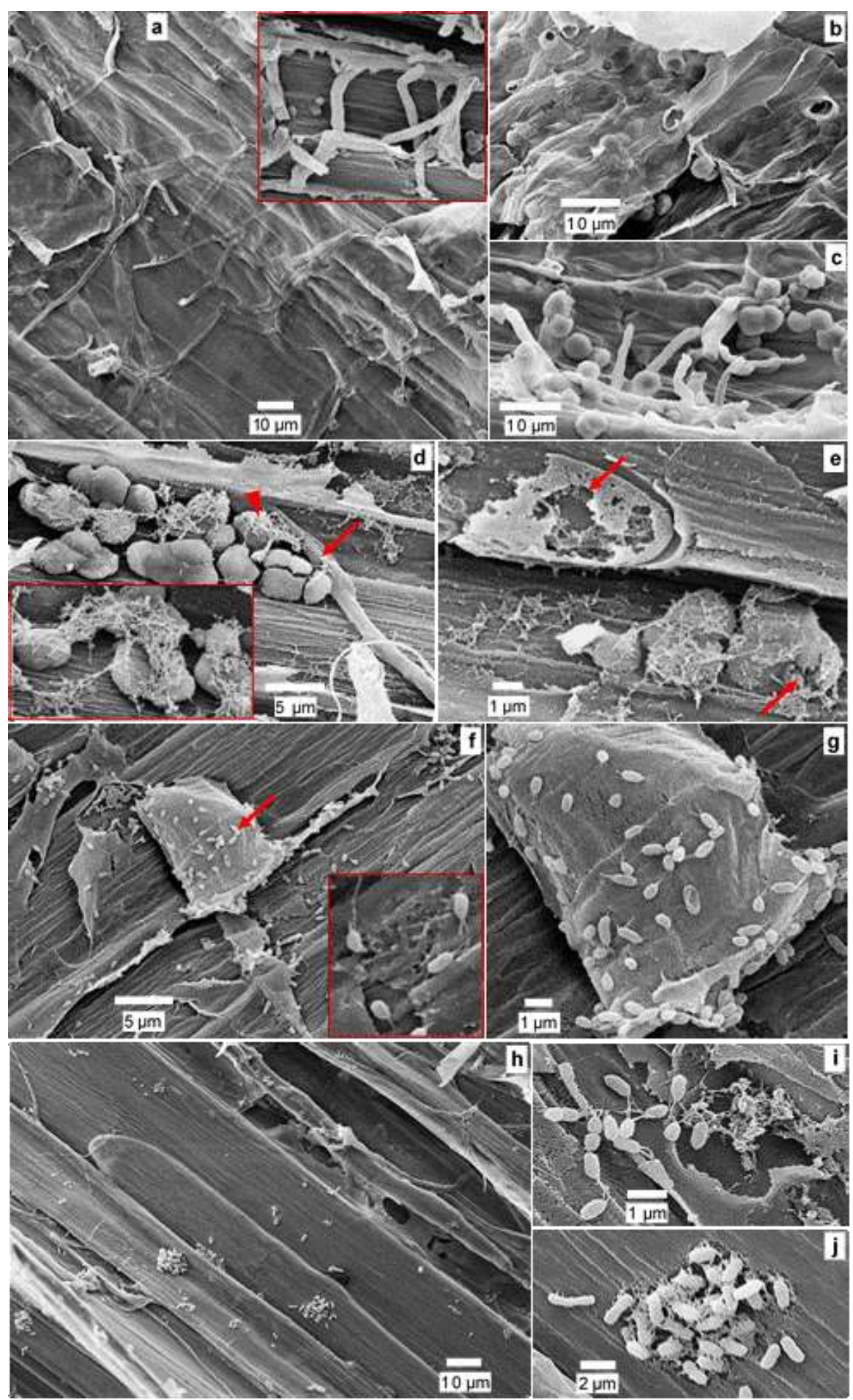

Fig. 13. LS sections through the epidermis and bast fibre regions after prolonged retting: $(a, b$, and c) intense hyphal colonization and association with chloroplasts in the epidermal palisade cells (inset in a, and c); ( $d$ and e) hyphae degraded chloroplasts (arrows in e), note the extracellular slimy materials on the chloroplasts were presumably produced during exoenzymatic decay (inset and arrowhead in $\mathrm{d}$, and e); and (f, $\mathrm{g}, \mathrm{h}, \mathrm{i}$, and j) bacteria and their attack are present within the epidermal cells (arrow in $\mathrm{f}$, and $\mathrm{g}$ ), note the bacteria with surface appendages (flagella/pili) for motility (inset in $\mathrm{f}$, and $\mathrm{g}$ ), and fibres and parenchyma within the bast regions (h) with decaying cell walls and cytoplasmic materials (i) or localized degradation of the outer wall layers of the fibres ( $h$ and $j$ ) are visible. 


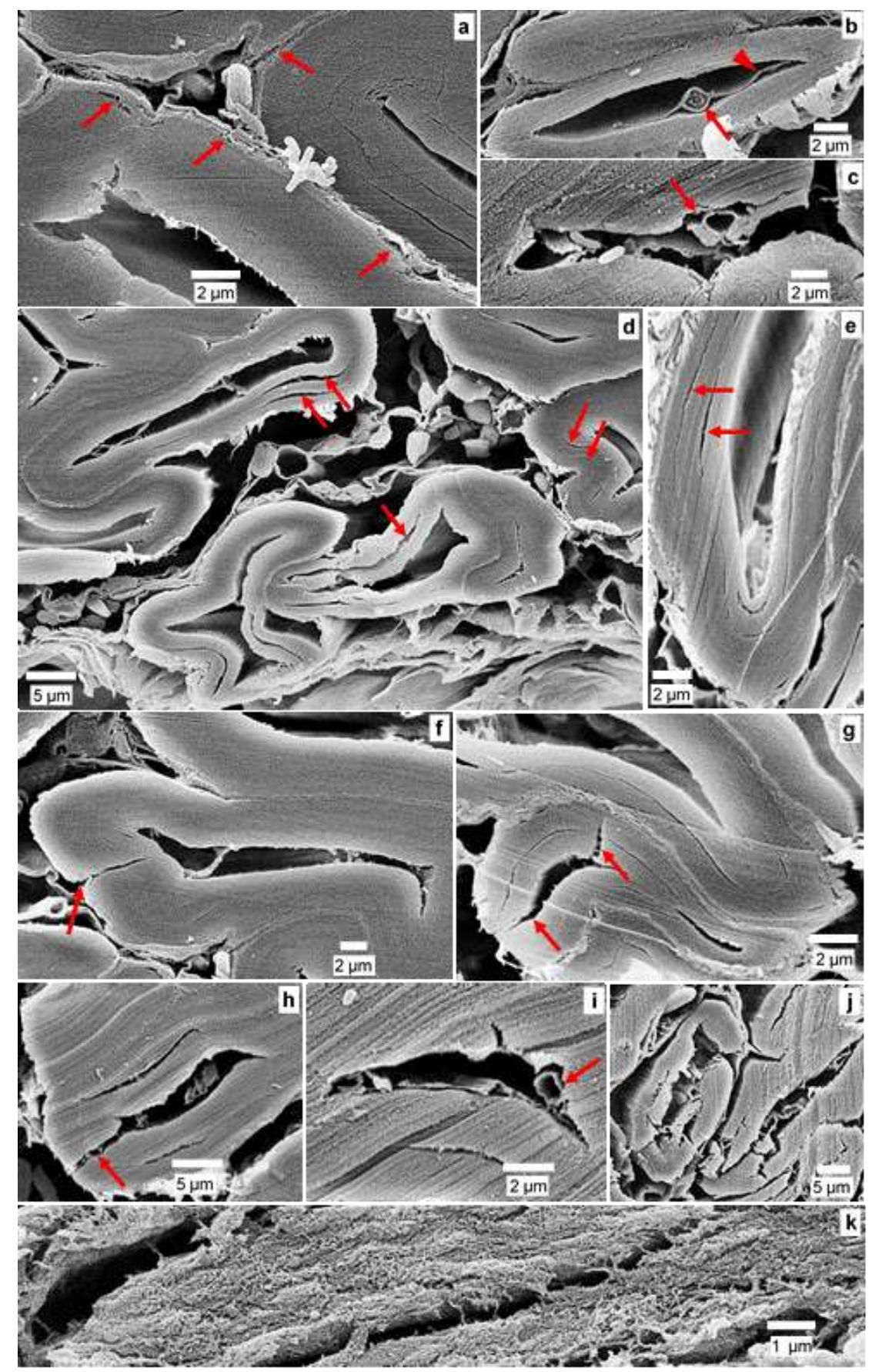

Fig. 14. Ultrastructural characteristics of hemp fibres after prolonged retting. a) Compound middle lamella $(\mathrm{CML})$ of primary fibres were partially degraded and delaminated (arrows) (note bacteria in close proximity). b) Hypha (arrow) present within the lumen and attached to the inner S3 layer of a fibre causing decay and its delamination (arrowhead). c) Hypha in cell lumen degrading the inner part of the S2 layer (arrow). d-k) Ultrastructural modification of the thick S2 layer of primary bast fibre through microbial attack showing: (i) cracking/intrawall fracturing within the S2 that follows the wall concentric lamellation (arrows in d, e), (ii) transwall fractures (cracks across S2) (arrow in f, g), (iii) micro-crack propagation and enlargements in S2 resulting in removal of wall polymers due to enzymatic hydrolysis within micro-cracks (arrow, h), (iv) S2 thinning (direct removal of S2 layer) from lumen side (arrow, i, c), and (v) intensely decayed S2 layer showing severely broken fibre wall (j) and microfibril structures likely resulting in degrading cell wall polymers (k). 
Table 3. Highlights of the Microbial Dynamics and Progressive Colonization and Degradation of the Hemp Stem Structure and Bast Fibres Observed during Field Retting

\begin{tabular}{|c|c|c|c|c|}
\hline Retting Time & $0 d$ & $7 d$ & $14 \mathrm{~d}$ and $20 \mathrm{~d}$ & After $50 \mathrm{~d}$ \\
\hline $\begin{array}{c}\text { Changes in the } \\
\text { Morphology/Ultrastructure } \\
\text { of the Hemp Stem and } \\
\text { Fibres }\end{array}$ & $\begin{array}{l}\text {-Stem with intact } \\
\text { layered structure } \\
\text {-Un-collapsed, } \\
\text { intact cells with } \\
\text { native cell geometry } \\
\text {-Cytoplasm-filled } \\
\text { living cells } \\
\text {-Clear surface with } \\
\text { undamaged cuticle } \\
\text { and trichomes } \\
\text {-Abundant } \\
\text { chloroplasts in the } \\
\text { upper epidermis }\end{array}$ & $\begin{array}{c}\text {-Overall structure } \\
\text { intact } \\
\text {-Fungal presence } \\
\text { on the surface and } \\
\text { inside of the stems } \\
\text {-Cellular anatomy } \\
\text { is less stable with } \\
\text { deformed } \\
\text { epidermis and } \\
\text { parenchyma }\end{array}$ & $\begin{array}{l}\text {-Cuticle severely } \\
\text { decayed } \\
\text {-Changes to the } \\
\text { cellular anatomy and } \\
\text { major destruction of } \\
\text { the living cells } \\
\text {-Fibre bundles } \\
\text { separated from the } \\
\text { epidermis and each } \\
\text { other } \\
\text {-Thick-walled cells } \\
\text { seldom colonized } \\
\text {-Parenchyma totally } \\
\text { degraded, but } \\
\text { chlorenchyma has } \\
\text { less damage } \\
\text {-Bast fibres with } \\
\text { infrequent mild attack } \\
\text {-Fibre morphology } \\
\text { affected the } \\
\text { characteristics of } \\
\text { colonization and the } \\
\text { decay morphology }\end{array}$ & $\begin{array}{l}\text {-Hemp structure severely affected } \\
\text { and disintegrated } \\
\text {-Extensively colonized epidermis } \\
\text { and cambium with dominant bacteria } \\
\text {-Complete destruction of the } \\
\text { parenchyma cells and loss of } \\
\text { structural integrity in the bast regions } \\
\text { - Hyphae inside of the lumina of all of } \\
\text { the cell types, including the fibres } \\
\text {-Intensified BFls inside of the stem } \\
\text {-Major loss to the anatomy and } \\
\text { ultrastructure } \\
\text {-Thick-walled bast fibres with decay } \\
\text { characteristics } \\
\text {-Effects on the fibre wall } \\
\text { ultrastructure: } \\
\text { a) loosening/degradation of the } \\
\text { CML, which led to delamination and } \\
\text { defibration } \\
\text { b) loosening and decay of the S3 } \\
\text { layer } \\
\text { c) prominent effect on the S2 layer } \\
\text { with delamination within the S2 } \\
\text { transwall, and intrawall fractures in } \\
\text { the S2 } \\
\text { d) Direct removal of S2 materials } \\
\text { (e.g., S2 thinning, broken S2, and } \\
\text { disintegration into nano-sized } \\
\text { cellulose fibrillar structures) }\end{array}$ \\
\hline $\begin{array}{l}\text { Microbial Dynamics and } \\
\text { Activities (Fungi/Bacteria) }\end{array}$ & $\begin{array}{c}\text {-Fungi rarely seen } \\
\text {-Bacteria not } \\
\text { observed }\end{array}$ & $\begin{array}{l}\text { Fungi: } \\
\text {-Sparsely growing } \\
\text { mycelia; less } \\
\text { diverse } \\
\text {-Colonization } \\
\text { outside of the } \\
\text { cortical layers, }\end{array}$ & $\begin{array}{c}\text { Fungi: extensive and } \\
\text { abundant } \\
\text {-Dense mycelia over } \\
\text { cuticle } \\
\text {-Diverse population } \\
\text {-A variety of abundant } \\
\text { spores }\end{array}$ & $\begin{array}{l}\text { Fungi: less abundant on the outside } \\
\text { of the stem } \\
\text {-Surface mycelia in non-living state, } \\
\text { but active hyphae inside of the stem } \\
\text {-Mycelia an exclusive source of } \\
\text { nutrients for the invading bacteria, } \\
\text { which reflected bacterial mycophagy } \\
\text { (i.e., extracellular and endocellular }\end{array}$ \\
\hline
\end{tabular}




\section{bioresources.com}

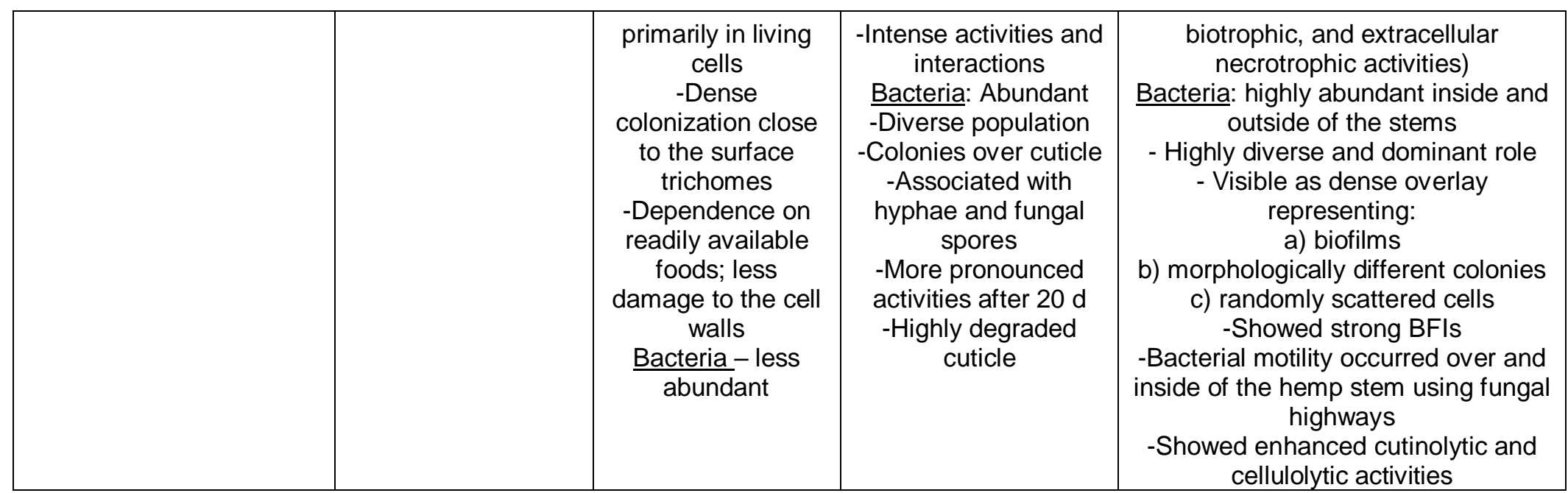


As was described by Thygesen et al. (2013), selective degradation of the thin transition lamellae possessing a different chemical composition (i.e., pectin and lignin) compared with adjacent cellulose-rich thick layers likely caused delamination of the S2 layer.

Cracks were also observed across the S2 layer that led to transwall fracture behaviour, which indicated weakening of the cellulose-rich S2 wall (Figs. 14f and 14g). Fractures developed both inwards (from CML towards lumen; arrow in Fig. 14f) and outwards (from lumen side to outer CML; arrows in Fig. 14g) because of microbial attack from both sides of the cell wall. Also, evidence for direct removal of the cell wall materials which occurred in different ways was visualized (Figs. 14h and 14k), and included: a) hyphae growing inside of the $\mathrm{S} 2$ wall and hydrolysing cellulose substrate within the spaces derived from the micro cracks (arrow in Fig. 14h); b) S2 thinning from the lumen surface close to the hyphal wall taking the shape of hyphae (arrow in Figs. 14c and 14i); and c) during severe attack, the bast fibres were intensely degraded with broken walls (Fig. 14j) and nano-sized fibrillar structures appeared in the transverse surfaces (Fig. 14k). Detrimental impact of the microbial enzymatic activity on the bast fibres after prolonged retting was therefore apparent. Ultrastructural changes, including loss of the S2 wall integrity, collectively resulted in inferior hemp raw materials and caused greatly deteriorated fibre characteristics and thus quality. Table 3 gives an overview of the natural field retting process that showed progressive colonization and resulting degradation of the hemp stem cellular structure and cells.

In light of the comprehensive findings in the present work, the following useful approaches could be suggested as management tools and/or better implementation of the retting process while rendering an important foundation for future studies on field retting: (a) for determining favorable extent of retting, quick visual investigation of fungal and bacterial populations could be performed using light microscopy with regular sampling between 2 to 4 weeks retting and optimum retting determined with the help of pectin staining using ruthenium red; (b) mechanical damage to the stem surface for breaking down the cuticular sealing is recommended as well as regularly mixing up of stems on the field; (c) pre-inoculation of hemp stems soon after and/or in combination with the step (b) above using fungal strains having high cutinase activity and (d) controlling moisture (e.g. sprinkling water) in stems throughout the retting period for facilitating fungal growth depending on the prevailing weather conditions.

\section{CONCLUSIONS}

1. The present study explored mechanisms of retting process related to morphological aspects, including microbial colonization and development, during field retting of hemp fibres intended for use in biocomposite manufacturing. The work also unveiled for the first time the existence of bacterial-fungal interactions (BFIs) in the retting environment and its extensive involvement that can ultimately affect the quality of bast fibres.

2. Fungi were found to be the main players of hemp retting during the early stages, but with a longer retting period, bacteria outcompeted the fungi and eventually dominated the community. Prolonged retting attracted a greater bacterial community and evidence of bacterial mycophagy, including extracellular biotrophic, extracellular necrotrophic, 
and endocellular biotrophic behaviours that influenced the bacterial activity, were observed during long retting periods (i.e., $50 \mathrm{~d}$ to $70 \mathrm{~d}$ ). The latter scenario where bacterial-fungal endosymbiosis interaction occurs in nature during retting was reported for the first time, with the results showing activities adopted by the bacteria for active intrusion into the fungal cells without damaging the hyphal wall.

3. Filamentous fungi played an important role in bacterial dominance during prolonged retting by supplying a nutrient source and migration pathway (i.e., fungal highways) for bacterial colonization and distribution for their enhanced bio-accessibility of organic matter both inside and outside of the hemp stems.

4. The molecular analysis of the microbial community, mass loss, and chemical analysis of the hemp stem/fibres corroborated the results from the in-depth scanning electron microscopy (SEM) investigations, which indicated progressive colonization, attack, and degradation of the hemp cellular structure, including the bast fibres, with prolonged retting.

5. The mechanisms adopted by the fungi when penetrating the hemp stem structure during the initial invasion suggested that the effective retting time can be reduced by mechanical damage to the cuticle of the hemp stems before their deposition on the ground. Fungi as initial invaders contributed for easy separation and defibration of the bast fibres from the complex stem cellular structure that resulted from the initial extensive degradation of pectin-rich living cells (e.g., parenchyma) after two weeks of retting.

6. The microbial invasion and colonization were initially influenced by easily accessible nutrients within the hemp stems and impacted by the anatomy, chemistry, and morphology for the degrading ability, with the fibre morphology strongly affecting the characteristics and intensity of the bast fibre decay.

7. This study revealed the detrimental effects of prolonged retting caused by BFIs on the ultrastructure of the thick-walled bast fibres that affected all of the major wall layers. This was reflected by degradation of the compound middle lamella, delamination of the S2, intrawall and transwall fractures in the fibre wall, and direct removal of cell wall materials, which led to S2 thinning, broken walls, and emerging nano-size fibrillar structures. All of these features indicated greatly deteriorated fibre characteristics and an inferior hemp fibre quality.

8. The findings of the study have implications for better management of the field retting process and for mechanical treatments to hemp stems before deposition on the ground, inoculation of stems with fungi and moisture control during retting.

\section{ACKNOWLEDGMENTS}

The authors gratefully acknowledge the financial support provided by the Formas project (No. 2015-469: "Unravelling the 3-dimensional nanostructure of wood cell walls using electron tomography (3-D NanoWood)") and the Danish Council for Independent Research supporting the CelFiMat project (No. 0602-02409B: "High quality cellulosic fibers for strong biocomposite materials"). 


\section{REFERENCES CITED}

Akin, D. E. (2013). "Linen most useful: Perspectives on structure, chemistry, and enzymes for the retting flax," ISRN Biotechnology 2013. DOI: 10.5402/2013/186534

Alkorta, I., Garbisu, C., Llama, M. J., and Serra, J. L. (1998). "Industrial applications of pectic enzymes: A review,” Process Biochem. 33(1), 21-28. DOI: 10.1016/S00329592(97)00046-0

Amaducci, S., and Gusovius, H.-J. (2010). "Hemp - Cultivation, extraction and processing," in: Industrial Application of Natural Fibres: Structure, Properties and Technical Application, J. Müssig (ed.), John Wiley \& Sons, Chichester, UK, pp. 109134.

Andre, C. M., Hausman, J.-F., and Guerriero, G. (2016). "Cannabis sativa: The plant of the thousand and one molecules," Front. Plant Sci. 7. DOI: 10.3389/fpls.2016.00019

Arnous, A., and Meyer, A. S. (2008). "Comparison of methods for compositional characterization of grape (Vitis vinifera L.) and apple (Malus domestica) skins," Food Bioprod. Process. 86(2), 79-86. DOI: 10.1016/j.fbp.2008.03.004

Baker, C. J., and Bateman, D. F. (1978). "Cutin degradation by plant pathogenic fungi," Phytopathology 68, 1577-1584.

Bhuiyan, N. H., Selvaraj, G., Wei, Y., and King, J. (2009). "Role of lignification in plant defense," Plant Signaling \& Behavior 4(2), 158-159. DOI: 10.4161/psb.4.2.7688

Blanchette, R. A. (1991). "Delignification by wood-decay fungi," Annu. Rev. Phytopathol. 29, 381-403. DOI: 10.1146/annurev.py.29.090191.002121

Bos, H. L., Van Den Oever, M. J. A., and Peters, O. C. J. J. (2002). "Tensile and compressive properties of flax fibres for natural fibre reinforced composites," $J$. Mater. Sci. 37(8), 1683-1692. DOI: 10.1023/A:1014925621252

Brown, A. E., and Sharma, H. S. S. (1984). "Production of polysaccharide-degrading enzymes by saprophytic fungi from glyphosate-treated flax and their involvement in retting," Ann. Appl. Biol. 105(1), 65-74. DOI: 10.1111/j.1744-7348.1984.tb02803.x

Corbière-Nicollier, T., Gfeller Laban, B., Lundquist, L., Leterrier, Y., Manson, J.-A. E., and Jolliet, O. (2001). "Life cycle assessment of biofibres replacing glass fibres as reinforcement in plastics," Resour. Conserv. Recy. 33(4), 267-287. DOI: 10.1016/S0921-3449(01)00089-1

Crônier, D., Monties, B., and Chabbert, B. (2005). "Structure and chemical composition of bast fibers isolated from developing hemp stem," J. Agr. Food. Chem. 53(21), 8279-8289. DOI: 10.1021/jf051253k

Das, B., Chakrabarti, K., Tripathi, S., and Chakraborty, A. (2014). "Review of some factors influencing jute fiber quality," J. Nat. Fibers 11(3), 268-281. DOI: 10.1080/15440478.2014.880103

de Boer, W., Folman, L. B., Summerbell, R. C., and Boddy, L. (2005). "Living in a fungal world: Impact of fungi on soil bacterial niche development," FEMS Microbiol. Rev. 29(4), 795-811. DOI: 10.1016/j.femsre.2004.11.005

del Río, J. C., Gutiérrez, A., Rodríguez, I. M., Ibarra, D., and Martínez, Á. T. (2007). "Composition of non-woody plant lignins and cinnamic acids by Py-GC/MS, Py/TMAH and FT-IR," J. Anal. Appl. Pyrol. 79(1-2), 39-46. DOI: 10.1016/j.jaap.2006.09.003

Di Candilo, M., Bonatti, P. M., Guidetti, C., Focher, B., Grippo, C., Tamburini, E., and Mastromei, G. (2010). "Effects of selected pectinolytic bacterial strains on water- 
retting of hemp and fibre properties," J. Appl. Microbiol. 108(1), 194-203. DOI:

10.1111/j.1365-2672.2009.04409.x

Easson, D. L., and Molloy, R. (1996). "Retting - A key process in the production of high value fibre from flax," Outlook Agr. 25(4), 235-242. DOI:

10.1177/003072709602500405

Faix, O., Mozuch, M. D., and Kirk, T. K. (1985). "Degradation of gymnosperm (guaiacyl) vs. angiosperm (syringyl/guaiacyl) lignins by Phanerochaete chrysosporium," Holzforschung 39(4), 203-208. DOI: 10.1515/hfsg.1985.39.4.203

Fan, M., Dai, D., and Yang, A. (2011). "High strength natural fiber composite: Defibrillation and its mechanisms of nano cellulose hemp fibers," Int. J. Polym. Mater. 60(13), 1026-1040. DOI: 10.1080/00914037.2010.551347

Frey-Klett, P., Burlinson, P., Deveau, A., Barret, M., Tarkka, M., and Sarniguet, A. (2011). "Bacterial-fungal interactions: Hyphens between agricultural, clinical, environmental, and food microbiologists," Microbiol. Mol. Biol. R. 75(4), 583-609. DOI: 10.1128/MMBR.00020-11

Fuller, W. H., and Norman, A. G. (1944). "The nature of the flora on field-retting hemp," Soil Sci. Soc. Am. Pro. 9, 101-105.

Henriksson, G., Akin, D. E., Hanlin, R. T., Rodriguez, C., Archibald, D. D., Rigsby, L. L., and Eriksson, K.-E. L. (1997). "Identification and retting efficiencies of fungi isolated from dew-retted flax in the United States and Europe," Appl. Environ. Microb. 63(10), 3950-3956.

Hu, W., Ton-That, M.-T., Denault, J., Rho, D., Yang, J., and Lau, P. C. K. (2012). "Comparison between dew-retted and enzyme-retted flax fibers as reinforcing material for composites," Polym. Eng. Sci. 52(1), 165-171. DOI: 10.1002/pen.22060

Inglis, G. D., Yanke, L. J., and Selinger, L. B. (2011). "Cutinolytic esterase activity of bacteria isolated from mixed-plant compost and characterization of a cutinase gene from Pseudomonas pseudoalcaligenes," Can. J. Microbiol. 57(11), 902-913. DOI: 10.1139/w11-083

Jankauskienè, Z., Butkutè, B., Gruzdevienè, E., Cesevicienė, J., and Fernando, A. L. (2015). "Chemical composition and physical properties of dew- and water-retted hemp fibers," Ind. Crop. Prod. 75(Part B), 206-211. DOI: 10.1016/j.indcrop.2015.06.044

Joshi, S. V., Drzal, L. T., Mohanty, A. K., and Arora, S. (2004). "Are natural fiber composites environmentally superior to glass fiber reinforced composites?," Compos. Part A-Appl. S. 35(3), 371-376. DOI: 10.1016/j.compositesa.2003.09.016

Keiblinger, K. M., Hall, E. K., Wanek, W., Szukics, U., Hämmerle, I., Ellersdorfer, G., Böck, S., Strauss, J., Sterflinger, K., Richter, A., et al. (2010). "The effect of resource quantity and resource stoichiometry on microbial carbon-use-efficiency," FEMS Microbiol. Ecol. 73(3), 430-440. DOI: 10.1111/j.1574-6941.2010.00912.x

Kirby, R. (2005). "Actinomycetes and lignin degradation," Adv. Appl. Microbiol. 58, 125-168. DOI: 10.1016/S0065-2164(05)58004-3

Kohlmeier, S., Smits, T. H. M., Ford, R. M., Keel, C., Harms, H., and Wick, L. Y. (2005). "Taking the fungal highway: Mobilization of pollutant-degrading bacteria by fungi," Environ. Sci. Technol. 39(12), 4640-4646. DOI: 10.1021/es047979z

Kolattukudy, P. E. (1985). "Enzymatic penetration of the plant cuticle by fungal pathogens," Annu. Rev. Phytopathol. 23, 223-250. DOI:

10.1146/annurev.py.23.090185.001255 
Leveau, J. H., and Preston, G. M. (2008). "Bacterial mycophagy: Definition and diagnosis of a unique bacterial-fungal interaction," New Phytol. 177(4), 859-876. DOI: 10.1111/j.1469-8137.2007.02325.x

Liu, M., Ale, M. T., Kołaczkowski, B., Fernando, D., Daniel, G., Meyer, A. S., and Thygesen, A. (2017a). "Comparison of traditional field retting and Phlebia radiata Cel 26 retting of hemp fibres for fibre-reinforced composites," AMB Express 7(58). DOI: $10.1186 / \mathrm{s} 13568-017-0355-8$

Liu, M., Thygesen, A., Summerscales, J., and Meyer, A. S. (2017b). “Targeted pretreatment of hemp bast fibres for optimal performance in biocomposite materials: A review," Ind. Crop. Prod. 108, 660-683. DOI: 10.1016/j.indcrop.2017.07.027

Liu, M., Fernando, D., Daniel, G., Madsen, B., Meyer, A. S., Ale, M. T., and Thygesen, A. (2015). "Effect of harvest time and field retting duration on the chemical composition, morphology and mechanical properties of hemp fibers," Ind. Crop. Prod. 69, 29-39. DOI: 10.1016/j.indcrop.2015.02.010

Liu, M., Silva, D. A. S., Fernando, D., Meyer, A. S., Madsen, B., Daniel, G., and Thygesen, A. (2016). "Controlled retting of hemp fibres: Effect of hydrothermal pretreatment and enzymatic retting on the mechanical properties of unidirectional hemp/epoxy composites," Compos. Part A-Appl. S. 88, 253-262. DOI: 10.1016/j.compositesa.2016.06.003

Masaki, K., Kamini, N. R., Ikeda, H., and Iefuji, H. (2005). "Cutinase-like enzyme from the yeast Cryptococcus sp. strain S-2 hydrolyzes polylactic acid and other biodegradable plastics," Appl. Environ. Microb. 71(11), 7548-7550. DOI: 10.1128/AEM.71.11.7548-7550.2005

Mediavilla, V., Jonquera, M., Schmid-Slembrouck, I., and Soldati, A. (1998). "Decimal code for growth stages of hemp (Cannabis sativa L.)," Journal of the International Hemp Association 5(2), 65, 68-74.

Moebius, N., Üzüm, Z., Dijksterhuis, J., Lackner, G., and Hertweck, C. (2014). "Active invasion of bacteria into living fungal cells," eLife 3. DOI: 10.7554/eLife.03007

Munshi, T. K., and Chattoo, B. B. (2008). "Bacterial population structure of the juteretting environment," Microb. Ecol. 56(2), 270-282. DOI:10.1007/s00248-007-9345-8

Pickering, K. L., Beckermann, G. W., Alam, S. N., and Foreman, N. J. (2007). "Optimising industrial hemp fibre for composites," Compos. Part A-Appl. S. 38(2), 461-468. DOI: 10.1016/j.compositesa.2006.02.020

Pickering, K. L., Aruan Efendy, M. G., and Le, T. M. (2016). "A review of recent developments in natural fibre composites and their mechanical performance," Compos. Part A-Appl. S. 83, 98-112. DOI: 10.1016/j.compositesa.2015.08.038

Ribeiro, A., Pochart, P., Day, A., Mennuni, S., Bono, P., Baret, J.-L., Spadoni, J.-L., and Mangin, I. (2015). "Microbial diversity observed during hemp retting," Appl. Microbiol. Biot. 99(10), 4471-4484. DOI: 10.1007/s00253-014-6356-5

Rosemberg, J. A. (1965). "Bacteria responsible for the retting of Brazilian flax," Appl. Microbiol. 13(6), 991-992.

Samuels, L., Kunst, L., and Jetter, R. (2008). "Sealing plant surfaces: Cuticular wax formation by epidermal cells," Annu. Rev. Plant Biol. 59, 683-707. DOI: 10.1146/annurev.arplant.59.103006.093219

Schneider, T., Keiblinger, K. M., Schmid, E., Sterflinger-Gleixner, K., Ellersdorfer, G., Roschitzki, B., Richter, A., Eberl, L., Zechmeister-Boltenstern, S., and Riedel, K. (2012). "Who is who in litter decomposition? Metaproteomics reveals major 
microbial players and their biogeochemical functions," ISME J. 6(9), 1749-1762.

DOI: 10.1038/ismej.2012.11

Sebastian, J., Chandra, A. K., and Kolattukudy, P. E. (1987). "Discovery of a cutinaseproducing Pseudomonas sp. cohabiting with an apparently nitrogen-fixing Corynebacterium sp. in the phyllosphere," J. Bacteriol. 169(1), 131-36.

Serrano, M., Coluccia, F., Torres, M., L'Haridon, F., and Métraux, J.-P. (2014). “The cuticle and plant defense to pathogens," Front. Plant Sci. 5(274). DOI: 10.3389/fpls.2014.00274

Simon, A., Bindschedler, S., Job, D., Wick, L. Y., Filippidou, S., Kooli, W. M., Verrecchia, E. P., and Junier, P. (2015). "Exploiting the fungal highway: Development of a novel tool for the in situ isolation of bacteria migrating along fungal mycelium," FEMS Microbiol. Ecol. 91(11). DOI: 10.1093/femsec/fiv116

Sinsabaugh, R. L., Hill, B. H., and Follstad Shah, J. J. (2009). "Ecoenzymatic stoichiometry of microbial organic nutrient acquisition in soil and sediment," Nature 462(7274), 795-798. DOI: 10.1038/nature08632

Tahir, P. M., Ahmed, A. B., Saiful Azry, S. O. A., and Ahmed, Z. (2011). "Retting process of some bast plant fibers and its effect on fibre quality: A review," BioResources 6(4), 5260-5281. DOI: 10.15376/biores.6.4.5260-5281

Tarkka, M. T., Sarniguet, A., and Frey-Klett, P. (2009). "Inter-kingdom encounters: Recent advances in molecular bacterium-fungus interactions," Curr. Genet. 55(3), 233-243. DOI: 10.1007/s00294-009-0241-2

Thygesen, A., Liu, M., Meyer, A. S., and Daniel, G. (2013). "Hemp fibres: Enzymatic effect of microbial processing on fibre bundle structure," in: Proceedings of the $34^{\text {th }}$ Risoe International Symposium on Materials Science, Roskilde, Denmark, pp. 373380.

Wang, B., Sain, M., and Oksman, K. (2007). "Study of structural morphology of hemp fiber from the micro to the nanoscale," Appl. Compos. Mater. 14(2), 89-103. DOI: 10.1007/s10443-006-9032-9

Wang, Y., and Dai, C.-C. (2011). "Endophytes: A potential resource for biosynthesis, biotransformation, and biodegradation," Ann. Microbiol. 61(2), 207-215. DOI: 10.1007/s13213-010-0120-6

Yeats, T. H., and Rose, J. K. C. (2013). "The formation and function of plant cuticles," Plant Physiol. 163(1), 5-20. DOI: 10.1104/pp.113.222737

Article submitted: December 21, 2018; Peer review completed: February 25, 2019; Revised version received: March 21, 2019; Accepted: March 22, 2019; Published: March 29, 2019.

DOI: 10.15376/biores.14.2.4047-4084 